NORTH AMERICAN ICHNEUMON-FLIES, NEW AND DESCRIBED, WITH TAXONOMIC AND NOMENCLATORIAL, NOTES.

By R. A. Cushman,

Of the Bureau of Entomology, United States Department of Agriculture.

This paper includes corrections to Viereck's "Type species of the genera of Ichneumon-flies," published as Bulletin 83 of the United States National Museum, and extensive additions to my own revision of the tribe Cremastini ${ }^{1}$, together with the descriptions of 1 new genus, 1 new subgenus, and 23 new species of Ichneumonidae, and 3 new species of Braconidae.

\title{
Family ICHNEUMONIDAE.
}

Subfamily JoppINAE.

Genus PHAEOGENES Wesmael.

PHAEOGENES ARCTICUS, new species.

At once distinct from any described North American species by the insensely black immaculate body and antennae and bright reddish testaceous legs.

Female.-Length, $6 \mathrm{~mm}$; antennae, $3.5 \mathrm{~mm}$.

Head finely punctate, temples sparsely, face more densely so, behind eyes nearly as broad as eyes; temples strongly convex; occiput deeply concave; face medially elevated; clypeus transverse, nearly twice as broad as long, apex rounded, sparsely punctate, margin finely foveolate, deeply separated from face, the foveae large and deep; cheeks slightly buccate; malar space nearly as long as basal width of mandible; antennae rather short and stout, scape only weakly oblique at apex, about as long as first joint of flagellum, the latter about twice as long as thick; mandibles narrowed apically, lower tooth much shorter than upper; pronotum, mesoscutum, and scutellum polished, with well-separated punctures coarsest in middle of mesoscutum; notauli briefly impressed, mesopleurum and metapleurum punctate-striate, the former polished in dorso-posterior angle; sternauli well defined for about half the length of the mesopleurum; propodeum with carinae strong, upper hind angles angulate, areola hexagonal, about as wide as long; petiolar area comprising about half dorsal surface of propodeum, slightly concave,

1 Proc. U.S.Nat.Mus., vol.53,1917,pp.503-551. 
transversely striate, propodeum otherwise coriaceous; legs stout; hind coxae with a small, acute tooth beneath at apex; wings reaching to apex of abdomen; areolet nearly equilaterally pentagonal; second intercubitus distinct though largely bullated; nervellus perpendicular; abdomen narrow fusiform; petiole strongly flattened; postpetiole longitudinally rugulose; second tergite with gastrocoeli shallow, distant from base, this and following tergites coriaceous, subopaque, apical tergite polished; lunulae distinct on second and third tergites, circular; ovipositor extending slightly beyond apex.

Black; antennae slightly brownish; tegulae and mandibles piceous; legs bright rufo-testaceous, apices of hind femur and tibia and their tarsi largely fuscous; wings slightly blackish hyaline, venation blackish, wing base white.

Male.-Length, $7 \mathrm{~mm}$; antennae, $6 \mathrm{~mm}$.

Except for the usual sexual differences of more slender abdomen, longer and more slender antennae, and lack of the coxal tooth, difiers in having the scape brownish beneath, and the clypeus, mandibles, a larger or smaller spot on each side of face, and the tegulae basally white.

Host.-Peronea, species, on spruce and hemlock.

Type locality.-Tongas National Forest, Alaska.

Type.-Cat. No. 22849, U.S.N.M.

Described from three females and five males reared at Washington, District of Columbia, under Hopkins U. S. No. 13448, from material collected by A. J. Jaenicke.

Paratype $b$, female, is slightly larger than the type, while $c$, male, bears the same relation to the allotype. Paratype $c$ also has the facial spots much larger than those of the allotype.

\section{Genus ISCHNOPSIDEA Viereck.}

Ischnus AUTHors, not Gravenhorst.

Only one North American species has been described in this genusnamely, Ischnus americanus Ashmead-but it does not belong here but to Atractodes. Nor do any species of the genus appear to have been described under other generic names. Viereck ${ }^{1}$ synonymized Posocentrus Provancher with Ischnus presumably on the strength of a misdetermination by Ashmead of the genotype, Posocentrus huarti Provancher, in the United States National Museum. Under this name are two females, one labeled "Sh. 30.9.96" and the number 665 , and the other "Sh. 7, 10,95" and numbered apparently 358. These represent a very distinct species, which I do not describe for lack of information as to the source of the specimens. A male of apparently the same species is from Cornwall, Idaho, collected August 1, 1898, by C. V. Piper. 
ISCHNOPSIDEA COLORADENSIS, new species.

In Berthoumieu's ${ }^{1}$ key to the European species runs to nigricollis (Wesmael), but differs in having the abdomen entirely black. From the closely allied truncator (Fabricius) it differs in having the entire thorax, even the scutellum, black; the third tergite transverse; and the antennae white annulate.

Female.-Length, $8 \mathrm{~mm}$; antennae, $5 \mathrm{~mm}$.

Head large, seen from above nearly as broad behind eyes as at eyes; temples weakly convex, extending nearly straight backward, and nearly as wide as short diameter of eye; eyes rather small, broadly oval; malar space nearly half as long as eye; eyes slightly divergent below; vertex slightly, face distinctly, broader than height of eye; clypeus distinctly truncate at apex, with the labrum slightly protruding; cheeks broad, buccate; head strongly punctate, throughout, face densely so; thorax strongly punctate, mesoscutum and scutellum rather sparsely so, notauli distinct to about middle of mesoscutum, scutellum margined to middle; propodeum densely punctate-rugulose above, transversely rugose behind, areola pentagonal, only slightly narrower at apex than at costulae, petiolar area not distinctly defined laterally; petiole subpolished, postpetiole opaque laterally, subpolished and weakly striate medially; other tergites opaque punctate; gastrocoeli nearly meeting in middle.

Black; antennae with apices of joints pale and a white annulus on flagellar joints 11-12; mandibles, tegulae, wing bases, and small humeral spot white; legs testaceous, hind tibia and tarsus slightly infuscate, middle and hind tibiae narrowly white at base.

Type locality.-Colorado.

Type.-Cat. No. 22850 , U.S.N.M.

Described from two females from the C. F. Baker collection.

The paratype is about a millimeter shorter than the type, with the abdomen slightly reddish, but is otherwise much like the type.

\section{Subfamily CRYPTINAE.}

Genus ATRACTODES Gravenhorst.

(ISCHNUS) ATRACTODES AMERICANUS (Ashmead).

\section{Genus SPILOCRYPTUS Thomson.}

SPILOCRYPTUS PROPODEUM, new species.

Male.-Length, $5.5 \mathrm{~mm}$; antennae, $5.5 \mathrm{~mm}$.

Differs from the male of polychrosidis Cushman principally as follows: Eyes sinuately emarginate opposite antennae; temples broader and more strongly convex; propodeal carinae weaker, the apical carina obsolete; thorax more coarsely sculptured throughout; mesoscutum with distinct, separated punctures, polished;

1 Ann. Soc. Ent. France, vol. 65, 1896, p. 389. 
mesopleur strongly, obliouely striate; prop deum sparsely punctate before basal carina, rugosely roughened beyond; sides of areolet parallel; tergites callose apically, giving the abdomen the appearance of being constricted at the sutures.

In color much like the paler specimens of polychrosidis, but inner orbits obscurely brownish; pronotum above, scutellum, and posterior face of propodeum white, thorax otherwise black; antennae not white annulate; abdomen ferruginous with basal half of second tergite, sutures, and apical tergites black, seventh tergite with a white mark; middle joints of hind tarsus not white but fuscous with base reddish as is also the basal joint.

Host.-Polychrosis viteana Clemens.

Type locality.-North East, Pennsylvania.

Type.-Cat. No. 22851, U.S.N.M.

Described from two males reared July 5, 1917, from cocoons of host, under Quaintance No. 14456.

In Provancher's key to Cryptus ${ }^{1}$ runs to exilis Provancher.

\section{Genus CHROMOCRYPTUS Ashmead.}

The undescribed type of this genus, Chromocryptus albopictus Ashmead MS., has come to light in the national collection. It runs in Thomson's Opuscula Entomologica key ${ }^{2}$, directly to Habrocryptus Thomson. This is the genus from which it is finally separated by Ashmead in his original description. In general form and structure the genus is very similar to (Habrocryptus) $=$ Ischnus Gravenhorst as represented by assertorius Fabricius and brachyurus Gravenhorst. It differs from Ischnus principally in having the head, especially the cheeks and temples, more rounded; the malar space shorter; the eyes less bulging; the antennae attenuate at apex; the thorax more coarsely and distinctly sculptured; the radius originating at the middle of the stigma; the areola with the intercubiti nearly parallel; the discoidal and brachial cells relatively shorter; the propodeum shorter, with the posterior face precipitate and concave, nearly completely areolated, the upper angles dentate, and the spiracles not quite circular; the first tergite distinctly elbowed and with the postpetiole more distinctly set off; the other tergites more coarsely and distinctly punctate. The body is more strikingly colored, the thorax and abdomen being tricolored and the coxae testaceous instead of black.

\section{CHROMOCRYPTUS ALBOPICTUS Ashmead.}

Female.-Length, $9 \mathrm{~mm}$; antennae, $7 \mathrm{~mm}$; ovipositor, $2 \mathrm{~mm}$.

Head from above nearly twice as wide as long; temples nearly perpendicular to longitudinal axis of body, nearly flat; vertex precipitate behind, punctate; frons irregularly rugoso-punctate; eyes 
large, broad oval, nearly parallel within, the inner orbits above slightly tumid; face densely finely punctate, slightly elevated medially; clypeus set of by a broad groove, with a transverse apical impression extending entirely across, the apex broadly truncate, leaving a distinct opening between it and the mandible; mandibles narrowed at apex, equally bidentate; basal joints of flagellum long and slender, the first slightly longer than second, this distinctly longer than third, others gradually decreasing in length to near apex where they are quadrate, the flagellum attenuate at apex. Thorax coarsely sculptured throughout; pronotum laterally rugose, epomia distinct nearly to dorsal margin, which is slightly tumid; mesoscutum densely, confluently punctate, notauli distinct, subfoveolate (the pin obscures the posterior ends of the notauli, but they are sharp at least halfway back on the mesoscutum); scutellar fovea deep and with a few longitudinal striae; scutellum sparsely punctate, its lateral areas strongly longitudinally striate; postscutellum medially bifoveate, its lateral areas striate; mesopleurum rugoso-punctate above, densely punctate below, sternauli incomplete but deep, foveolate, curved dorsally; sternum densely punctate; prescutal carina complete; metapleurum and propodeum coarsely rugoso-punctate, the latter with short, blunt apophyses, behind which the surface is very coarsely reticulate ruguse, areolation nearly complete, only the lateral longitudinal carinae being entirely wanting; nervulus slightly antefurcal; areolet pentagonal, sides slightly convergent, the intercubiti forming the longest sides; second recurrent straight, with a single broad bulla; nervellus broken far below middle, slightly inclivous; legs slender. First tergite polished, spiracles at apical fourth, petiole slender, postpetiole about four times as broad as petiole, dorsal carinae wanting, lateral carinae complete to apex; second and third tergites broad, strongly arched, callose at apex, densely, finely punctate; other tergites short, subpolished; ovipositor sheath about one and one-half times as long as first tergite.

Head black, orbits except narrow interruption in malar space, spot on clypeus, and spot on each mandible yellow; antennae black, with an incomplete white annulus on flagellar joints 6-11. Thorax black above, mesosternum and lower pleura, metasternum and pleura ferruginous, this color extending above bases of apophyses; anterior and superior margins of pronotum, two short lines on middle of mesoscutum, scutellum largely, a line on dorsal margin of mesopleurum and a spot just above sternaulus, an obscure spot at base of hind wing, upper portion of metapleurum, and the sides of the posterior face of the propodeum including the apophyses yellowish; legs testaceous; front and middle coxae in front and their basal trochanters apically and ventrally white; hind tibia at apex, basitarsus at base, and apical tarsal joint fuscous, tarsus otherwise white; 
wings hyaline. First three tergites ferruginous, the third somewhat piceous; other tergites black, margined with white apically.

Type locality.-Urbana, Illinois.

Type.-Cat. No. 22852, U.S.N.M.

Described from the unique Ashmead type.

In his key to his family Phygadeuontoidae Foerster ${ }^{1}$ includes a group of three genera separated from those that follow them by having the face clothed with glittering silky pile and with notauli extending at least to the middle of the mesoscutum. These are, in the order of their occurrence, Thysiotorus, Apsitops, and Panargyrops. The first is separated from the other two by its unbroken nervellus. On an earlier page (175) of the same work and in the family Hemiteloidae he separated off two other genera by identically the same characters. These are Ischnurgops and Sieganops. Earlier in the key to the Hemiteloidae the nervellus character is employed. These two characters, the facial pubescence and the form of the nervellus, were therefore used by Foerster in one order in the Phygadeuontoidae and in the opposite order in the Hemiteloidae. Among the genera distinguished from Ischnurgops and Steganops, in which the nervellus is said not to be broken, is Bathythrix (p. 176) said to have a broken nervellus. The only character given by Foerster for separating the Hemiteloidae and Phygadeuontoidae is the incomplete areola of the former and the complete one of the latter. To none of these genera did Foerster assign species, and the only description of either that he offered is the sum of the characters that lead to it in the keys, including the characters employed to separate his families. To certain of these genera species have been assigned by later authors, as follows, only the first inclusion of species being listed:

Panargyrops (Foerster) Schmiedeknecht. Zool. Jahrb., vol. 3, 1888, p. 435. Two species: Cryptus claviger Taschenberg and Leptocryptus heteropus Thomson.

Thysiotorus (Foerster) BrischKe. Schr. naturf. Ges. Danzig, new ser., vol.7, 1891, pt.4, p.71. Two species: Hemiteles (Physiotorus) (sic) brevipennis Brischke and Hemiteles (Physiotorus) (sic) similis Brischke.

Apsilops (Foerster) Ashmead. Trans. Amer. Ent. Soc., vol. 23, 1896, p. 207. One species: Cryptus hirtifrons Ashmead.

Bathythrix (Foerster) Howard. Bull. U. S. Dept. Agr., Bur. Ent., tech. ser. No. 5, 1897, p. 53. Two species: Bathythrix meteori Howard and Bathythrix pimplae Howard.

The first-mentioned species in each case was designated by Viereck ${ }^{2}$ as the genotype. 
In 1873 Thomson ${ }^{1}$ first proposed his genus Leptocryptus in a key to the genera of Phygadeuonini. In a note following the key he says:

"Of Leptocryptus, which in some ways is related to the Ophioninae, I know of no described species unless Taschenberg's Panargyrops claviger should possibly be referred here" (translation from the Swedish by Dr. Adam Böving).

The genus was not further characterized until 1884, when Thomson ${ }^{2}$ published a formal description and tabulated and described nine species-claviger Taschenberg, strigosus Thomson, lamina Thomson, aereus Gravenhorst, brevis Thomson, pellucidator Gravenhorst, geniculosus Thomson, rugulosus Thomson, and ruficandatus Bridgman.

In 1905 and 1908 Schmiedeknecht $^{3}$ placed Apsilops, Thysiotorus, and Panargyrops in synonymy with Leptocryptus with the statement:

The three Foersterian genera constitute the genus Leptocryptus, so neither name can be used for the united genus; they can not even be used to designate subgenera, since they are not sharply separable.

Roman ${ }^{4}$ unites all of the genera thus far mentioned, except Bathythrix, together with Ocymorus Foerster under Leptocryptus, designating Panargyrops as a subgenus. The only species mentioned is claviger Taschenberg, which is definitely placed under the heading "Untergatt. Panargyrops Först." On the strength of this Vierecks designated claviger as the type of Ischnurgops and Steganops. This is obviously not in accord with the intention of Roman. The fact that Leptocryptus and Panargyrops are isogenotypic does not alter the case, for Roman says that the genus is divisible into two subgenera, one of which is Panargyrops and the other composed of the other Foersterian genera.

It seems to the writer that Ischnurgops and Steganops, together with Ocynorus which Viereck overlooked in his wholesale attempt at suppression of generic names, must be considered as still without properly included species. Furthermore, claviger differs from the descriptions of Ischnurgops and Steganops in having the areolet closed, and from the former further in not having the face strongly narrowed below. In the Phygadeuontoidae it can run only to Panargyrops, and this is the only Foersterian genus for which it can function as type. Although its first inclusion in Leptocryptus was somewhat doubtful, no such doubt was expressed by Thomson in his second mention of it; and Viereck's fixation of it as the type of that genus can not be questioned. Leptocryptus is therefore a strict synonym of Panargyrops.

1 Opusc. Ent., fasc. 5, 1873, p. 521 .

2 Idem., fasc. 10, 1884, pp. 963-966.

${ }^{3}$ Idem., fasc. 10, 1905, p. 727; Gen. Ins., fasc. 75, 1908, p. 9

4 Naturw. Unters. Sarekg., vol. 4, 1909, p. 236.

5 Bull. 83, U. S. Nat. Mus., 1914.

181404-21-Proc.N.M.vol.58-17 
Of the species included by Thomson in Leptocryptus only fourclaviger, lamina, ruficandatus, and geniculosus - are represented in the National Collection. Of these, lamina runs to Thysiotorus, ruficandatus to Apsilops, and geniculosus to Bathythrix. This last is congeneric with Bathythrix meteori Howard, the genotype, and Bathythrix pimplae Howard. Ruficaudatus is very different from Apsilops hirtifrons Ashmead. The latter species has as its congener Ichneumon cinctorius Fabricius, the first species referred to Dapanus Foerster (by Ashmead) and Sobas Foerster (by Schmiedeknecht) and the basis of Thomson's genus Trichocryptus. By Foerster's definition of the Cryptoidae, cinctorius can not be the type of Sobas, for the propodeal areola is complete and the dorsal carinae of the petiole are present. These characters, regardless of their value in the sense in which they are employed by Foerster and regardless of the strictness of Foerster's own interpretation of them, constitute a part of his descriptions of all his Phygadeuontoid genera and must be strictly interpreted in the selection of types for his atypic genera. In the Phygadeuontoidae cinctorius and hirtifrons will run to no genus, for they agree with neither alternate under category 7 . Therefore cinctorius can not serve as the type of Dapanus, nor hirtifrons of Apsilops. This leaves Trichocryptus Thomson as the name to be used for this genus, and Dapanus without properly included species. Subsequent to his inclusion of hirtifrons in Apsilops, Ashmead referred two other species to the genus, Diaglypta radiata Ashmead ${ }^{1}$ and Apsilops nigriceps Ashmead. ${ }^{2}$ Neither of these species is congeneric with hirtifrons. They belong rather to that group of the Hemitelini, in which the second intercubitus is entirely wanting and the first much reduced, and hence can not be types of the genera Diaglypta and Apsilops. Neither is more than subgenerically distinct from Allocota Foerster. Apsitops and Diaglypta are therefore without properly included species.

The two species referred by Brischke to Thysiotorus are unknown to the writer. They must both, however, be excluded as possible types of that genus for the areolet is lacking, whicn in Foerster's classification would place them in the Hemiteloidae instead of in the Phygadeuontoidae. The only other species referred to Thysiotorus is Mesoleptus peregrinus Cresson, so referred by Viereck. ${ }^{3}$

This species can not be the genotype of Thysiotorus Foerster since it has the nervellus broken as shown by a recent examination of the type. This leaves Thysiotorus Foerster without a genotype. Mesoieptus peregrinus Cresson is a Panargyrops and has as its synonym Panargyrops thoracicus Cushman.

1 Trans. Ent. Soc. Lond., 1900, p. 268.

2 Proc. U. S. Nat. Mus., vol. 29, 1905, p. 114.

3 Idem·, vol. 42, 1912, p. 645. 
Brischke, ${ }^{1}$ not Schmiedeknecht ${ }^{2}$ as cited by Viereck, was the first to assign a species to Chaeretymma Foerster. Brischke's inclusions were: Cryptus aereus Taschenberg, Cryptus ater Brischke, and Cryptus pellucidator Gravenhorst, all subsequently placed by Schmiedeknecht in Leptocryptus, ater being synonymized with claviger Gravenhorst. Cryptus aereus and pellucidator are unknown to the writer, but claviger can certainly not be the type of Chaeretymma, for it is Phygadenontoid by Foerster's definition, not Cryptoid, and differs in other ways from the description of Chaeretymma Foerster. Chaeretymma Brischke, with Cryptus ater Brischke as type, is synonymous with Panargyrops Foerster.

The following corrections to Viereck's catalogue of genotypes are therefore necessary:

(APSILOPS AshMEAD [1896])=TRICHOCRYPTUS THOMSON .

Trans. Amer. Ent. Soc., vol. 23, 1896, p. 207. One species.

Type: Cryptus hirtifrons Ashmead. (Monobasic.)

Genotype congeneric with that of Trichocryptus Thomson.

(APSILOPS Ashmead [1900])=ALLOCOTA Foerster.

Trans. Ent. Soc. Lond., 1900, p. 268. One species.

Type: Diaglypta radiata Ashmead. (Monobasic.)

(APSILOPS AsHMEAD [1905])=ALLOCOTA Foerster.

Proc. U. S. Nat. Mus., vol. 29, 1905, p. 114 . One species.

Type: Apsilops nigriceps Ashmead. (Monobasic.)

APSILOPS FoERSTER.

Verh. naturf. Ver. preuss. Rheinland, vol. 25, 1868, p. 182 . No species.

Neither of the three species referred to Apsilops by Ashmead agrees with the description.

Atypic.

(CHAERETYMMA BrischKe, not Foerster)=PANARGYROPS Foerster.

Schrift. naturf. Ges. Danzig, new ser., vol. 5, 1880, p. 338 . Three species.

Type: (Cryptus ater Brischke)=Panargyrops claviger (Gravenhorst). (By present designation.)

Isogenotypic with Panargyrops Foerster.

CHAERETYMMA Foerster (Schmiedeknecht).

Verh. nat. Ver. preuss. Rheinl., vol. 25, 1868, p. 187. No species.

Ent. Nach., vol. 16, 1890, p. 150. Four species.

Type: Cryptus furcator Gravenhorst, Thomson. (By designation of Viereck.)

None of the three species included in 1880 by Brischke agrees with the description of Chaeretymma Foerster and neither can be the type.

DAPANUS FoERSTER.

Verh. naturf. Ver. preuss. Rhcinland, vol. 25, 1868, p. $183 . \quad$ No species.

Ichneumon cinctorius Fabricius, designated by Ashmead as type, does not agree with description.

Atypic.

(DIAGLYPTA AsHMEAD)=ALLOCOTA FoERSTER.

Proc. Zool. Soc. Lond., 1895, p. 780. One species.

Type: Diaglypta radiata Ashmead. (Monobasic.)

1 Schrift. naturi. Ges. Danzig, new. ser., vol. 5, 1881, p. 338.

2 Ent. Nachr., vol. 16, 1890, p. 150. 
DIAGLYPTA FoERSTER.

Verh. naturf. Ver. preuss. Rheinland, vol. 25, 1868, p. 176. No species.

Diaglypta radiata Ashmead, the first species included, does not agree with original description.

Atypic.

ISCHNURGOPS FOERSTER.

Verh. nat. Ver. preuss. Rheinland, vol. 25, 1868, p. 175. No species.

Cryptus claviger Gravenhorst, designated as type by Viereck on supposed inclusion by Roman, was definitely excluded by Roman and furthermore does not agree with the description.

Atypic.

(LEPTOCRYPTUS CAMERON)=NEMATOPODIUS GRAVENHORST (according to Schmiedeknecht, Gen. Ins., fasc. 75, 1908, p. 149).

Mem. Manchester Lit. Philos. Soc., vol. 47, 1903, No. 14, p. 14.

Type: Leptocryptus longiventris Cameron. (Monobasic.)

(LEPTOCRYPTUS THOMSON)=PANARGYROPS FOERSTER.

Opusc. Ent., fasc. 5, 1873, p. 521. One species.

Opusc. Ent., fasc. 10, 1884, p. 963. Many species.

Type: Cryptus claviger Gravenhorst. (By designation of Viereck.)

(SOBAS SchmiedeKneCHT)=Trichocryptus Thomson.

Ent. Nachr., vol. 16, 1890, p. 113. One species.

Type: Ichneumon cinctorius Fabricius. (Monobasic.)

Isogenotypic with Trichocryptus Thomson.

(SOBAS FOERSTER, preoccupied.)

Verh. nat. Ver. preuss. Rheinland, vol, 25, 1868, p. 187. No species.

Ichneumon cinctorius Fabricius included by Schmiedeknecht does not agree with description.

Atypic.

STEGANOPS FOERSTER.

Verh. nat. Ver. preuss. Rheinland, vol. 25, 1868, p. 175 . No species.

Cryptus claviger Gravenhorst, designated as type by Viereck on supposed inclusion by Roman, was definitely excluded by Roman and does not agree with the description.

Atypic.

THYSIOTORUS BRISchKe, not Foerster.

Schr. naturf. Ges. Danzig, new ser., vol. 7, 1891, pt. 4, p. 71. Two species.

Type: Hemiteles (Physiotorus) (sic) brevipennis Brischke. By designation of Viereck.

(THYSIOTORUS VIERECK, not FOERSTER)=PANARGYROPS FOERSTER.

Proc. U. S. Nat. Mus., vol. 42, 1912, p. 645. One species.

Type: Mesoleptus? peregrinus Cresson. (Monobasic.)

THYSIOTORUS FOERSTER.

Verh. nat. Ver. preuss. Rheinland, vol. 25, 1868, p. 181. No species.

Hemiteles (Physiotorus) brevipennis and Hemiteles (Physiotorus) similis Brischke, included by Brischke, do not agree with description.

Atypic.

TRICHOCRYPTUS ThOMSON=(DAPANUS AsHMEAD, not Foerster; APSILOPS Ashmead (1896), not Foerster; SOBAS Schmiedeknecht, not Foerster). Opusc. Ent., fasc. 5, 1873, p. 520, 521 . One species.

Type.-Ichneumon cinctorius Fabricius. (Monobasic.)

The writer does not wish to be construed as saying that all of these erroneously selected genotypes are erroneously referred to the Foersterian genera, but simply that these particular species can not 
function as genotypes of the genera in which they were the first included species. Many of these genera are based at least partially on characters that are certainly not of generic value. But until the genera are defined by properly fixed types the improperly fixed types must be excluded from the genera, and, if necessary, new generic names, assigned to them.

\section{Genus PANARGYROPS Foerster.}

Four nearctic species of this genus are known to me, and a note by S. A. Rohwer in regard to the type of (Mesostenus) Mesoleptus sericeus (Provancher) indicates that it too belongs here. The iollowing key will separate the five species in the female. The male of only one species is known to me.

KEY TO NORTH AMERICAN SPECIES (FEMALES).

1. Thorax more or less rufous......................... peregrinus (Cresson).

Thorax entirely black......................................... 2 .

2. Front and middle coxae and trochanters white; hind trochanters more or

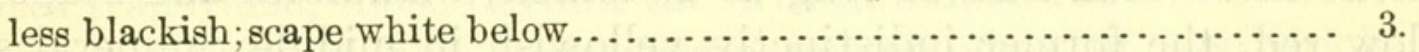

Front and middle coxae and trochanters testaceous; hind trochanters not at all blackish; scape not white below ............................. 4.

3. A line in front of tegula white..................... sericeus (Provancher).

White in front of tegula confined to humeral angle of pronotum.. tibialis (Cushman).

4. Tegulae pale; ovipositor barely two-thirds as long as abdomen or twice as long as first tergite ....................................... new species.

Tegulae fuscous; ovipositor nearly as long as abdomen or three times as long as first tergite............................................... new species.

PANARGYROPS SERICEUS (Provancher).

Mesostenus sericeus Provancher, Nat. Can., vol 7, 1875, p. 264, male.

Mesostenus sericeus Provancher, Nat. Can., vol. 11, 1879, p. 111, female.

Mesostenus sericeus Provancher, Faun. Nat. Can. Hym., 1883, p. 345, female, male.

Mesoleptus sericeus (Provancher), Faun. Ent. Can. Hym., 1883, p. 395.

Mesoleptus sericeus (Provancher), Addit. Faun. Ent. Can., Hym., 1889, p. 362.

This species may have as a synonym tibialis (Cushman); but in a series of 17 specimens of both sexes of tibialis, every one has the white of the pronotum confined to a small spot on the humeral angle, and the black of the hind trochanter is in almost every case confined to the apical joint. Aside from these two characters there is nothing in Provancher's description that does not apply equally as well to tibialis.

PANARGYROPS TIBIALIS (Cushman).

Bathythrix tibialis Cushman, Proc. U.S. Nat. Mus., vol. 53, 1917, p. 458, female, male.

Panargyrops tibialis (Cushman), Proc. U. S. Nat. Mus., vol. 55, 1919, p. 528.

A series of eight females and four males reared from the type host and received subsequent to the publication of the original descrip- 
tion shows considerable variation in the relative length of the tergites. The color is very constant except that one very small male has the hind coxae and both joints of the hind trochanter largely black. In the original description the length of the malar space should have been stated "slightly less than half as long as basal width of mandible."

\section{PANARGYROPS PEREGRINUS (Cresson).}

Mesoleptus? peregrinus Cresson, Trans. Amer. Ent. Soc., vol. 2, 1868, p. 102.

Thysiotorus peregrinus Viereck, Proc. U. S. Nat. Mus., vol. 42, 1912, p. 645.

Panargyrops thoracicus Cushman, Proc. U. S. Nat. Mus., vol. 55, 1919, p. 528.

PANARGYROPS TEXANUS, new species.

Female.-Length, $7.5 \mathrm{~mm}$; antennae, $4.5 \mathrm{~mm}$; ovipositor, 2.5 $\mathrm{mm}$.

Differs from tibialis (Cushman) principally as follows: Antennae stout, sixth flagellar joint barely twice as long as thick (in tibialis the sixth joint is much more than twice as long as thick); ovipositor little more than half as long as abdomen; mandibles and scape below red, the former indistinctly yellowish in middle; humeral spot reddish; legs, except hind tibiae and tarsi, testaceous, front pair considerably paler but coxae and trochanters are not white, hind tibiae and tarsi reddish fuscous, trochanters not at all black.

Type locality.-Texas.

Type.-Cat. No. 22853 , U.S.N.M.

One female from the Belfrage collection.

PANARGYROPS PACIFICUS, new species.

Female.-Length, $7 \mathrm{~mm}$; antennae, $5 \mathrm{~mm}$; ovipositor, $3 \mathrm{~mm}$.

Differs from tibialis (Cushman) principally as follows: Scape below indistinctly reddish; tegulae piceous; humeral angle of pronotum not marked; legs testaceous, front pair palest, coxae and trochanters not white, hind trochanter with apical joint only faintly darker; tergites without distinct whitish apical margins.

Type locality. San Juan Island, Washington.

Type _-Cat. No. 22854, U.S.N.M.

One female taken July 1-7, 1909, by W. M. Mann.

\section{Genus THYSIOTORUS Foerster.}

The new species described below is somewhat doubtfully referred to this genus.

As typified by the new species and its congener Leptocryptus lamina Thomson, Thysiotorus may be characterized as follows: Head transverse, broader than thorax, the temples strongly receding; eyes large, bulging, the inner margins straight and slightly convergent below; face narrow, little more than half as wide as eye is long, densely 
covered with long, shining, white pubescence; clypeus deeply transversely impressed before apex; malar space very short; cheeks very narrow; antennae slender, first flagellar joint much longer than second, which is subequal with the third; thorax clothed with rather long pubescence; notauli deep, terminating abruptly just before the scutellar groove; sternauli complete; propodeum with petiolar and posterior lateral areas confluent, otherwise completely areolated, with dense, long pubescence, the areola large, broadly hexagonal; wings broad; stigma and radial cell broad; areolet with the third abscissa of cubitus forming its shortest side, second intercubitus $l_{\text {argely bullated but distinct; nervellus unbroken; legs slender, hind }}$ tibia slightly swollen near base, first tarsal joint nearly as long as the other four combined; the last much shorter than third; abdomen rather slender, broadest much behind the middle; first tergite sublinear, postpetiole but little wider than petiole, spiracles nearly at the middle; second tergite narrow at base, much broader at apex, as long as first tergite, or nearly, gastrocoeli distant from base; other tergites transverse, those beyond the fifth in female retracted; abdomen with a median pale mark beginning on apex of postpetiole, broadening out at the apex of each segment to the full width of the segment, and extending to the apex, segments beyond second sometimes entirely reddish; ovipositor sheath subequal in length to first tergite.

THYSIOTORUS? SMITHI, new species.

Female.-Length, $5 \mathrm{~mm}$; antennae, $3.5 \mathrm{~mm}$.; front wing, $4 \mathrm{~mm}$.

Head and thorax polished, practically impunctate; malar space hardly half as long as basal width of mandible; propodeum opaque; areola nearly equilaterally hexagonal; first tergite with spiracles very slightly beyond middle; postpetiole parallel-sided, longitudinally striate; second tergite striate nearly to apex, third striate in basal half; ovipositor sheath almost exactly as long as first tergite.

Black, with the usual pale tergal mark; antennae pale at base; mandibles pale; palpi tegulae and front and middle coxae and trochanters whitish; legs otherwise stramineous, except hind femur, which is pale testaceous, its tibia, which is infuscate especially at base and apex, and its tarsus which is fuscous; wings hyaline, venation blackish.

Male.-Very similar to female.

Type.-Cat. No. 22855 , U.S.N.M.

Described from six females and two males, all collected by the late H. H. Smith, for whom the species is named. The series shows some minor variation in size, in the shape of the areola of the propodeum, and in the extent of the pale tergal mark. The last sometimes begins on the apex of the postpetiole and sometimes on the second tergite, the arnount of black laterally corresponding. 


\section{Type locality.-Coleta, Alabama.}

Other localities.-Pyziton, Clay County; and Langdale, Chambers County, Alabama.

\section{Subfamily TRYPHONINAE.}

\section{Genus PHTHORIMA Foerster.}

Only one North American species, Phthorima borealis Ashmead, ${ }^{1}$ has been referred to this genus. This species is not Diplazonine. I would place it in the Tryphonini, where it runs fairly satisfactorily in Ashmead's Key to Gastroporus Foerster, to which no species has as yet been assigned and to which I somewhat doubtedly refer it.

But two species from the United States have recently been found in the miscellaneous undetermined material in the National Museum and are described herewith. Of one of them Mr. H. L. Viereck has reared four specimens, which he has generously permitted the writer to add to the meager material already at hand. These specimens emerged from aphid galls on witch-hazel, where they were presumably parasitic on some species of Syrphid fly. The strongly compressed and extensible abdomen is evidently an adaptation for oviposition in the peculiar situation where its host lives.

(PHTHORIMA) GASTROPORUS? BOREALIS (Ashmead).

PHTHORIMA EXTENSOR, new species.

Female.-Length, $8.5 \mathrm{~mm}$.; abdomen, $6 \mathrm{~mm}$. (in an extended specimen of same size as much as $9 \mathrm{~mm}$.); antennae, $4.5 \mathrm{~mm}$.

Head strongly narrowed behind eyes; vertex very minutely coriaceous, subopaque; frons and face shining, minutely punctate; malar space scarcely as long as basal width of mandible and without a distinct furrow; clypeus flat with a narrow reflexed margin, truncate at apex, punctate; thorax above densely, finely punctate; pronotum shining, sparsely punctate above, coriaceous below; mesopleurum polished, sparsely, minutely punctate; sternum more densely so; sternauli broadly impressed; metapleurum opaque, punctato-rugulose; propodeum irregularly rugulose, especially on posterior face, the carinae indistinct, the posterior face not especially precipitous; areolet, sessile; nervulus strongly postfurcal; nervellus strongly broken not far below middle; compression of abdomen embracing more or less of second tergite, which is strongly sculptured only at base and scarcely half as wide at base as long; first tergite distinctly wider from base to spiracles than beyond; little more than half as wide at apex as long.

Black; middle of face, a larger or smaller spot at each side of clypeus, mandibles, palpi, a cuneiform spot on each side of mesoscutum adja- 
cent for its entire length to the pro-mesonotal suture, tegulae, humeral angle of pronotum, subalar spot, and meso-metapleural suture white or whitish; antennae black; front and middle legs pale testaceous, their coxae, trochanters and tarsi white, the last reddish at apex; hind coxae and femur testaceous, trochanter stramineous, tibia stramineous with apex reddish below and fuscous above, tarsal joints white, fuscous at apices, the last two joints entirely fuscous; wings hyaline.

Type locality.-Virginia shore of Potomac River, near Plummer's Island, Maryland.

Other locality.-Georgetown, District of Columbia.

Type.-Cat. No. 22856, U.S.N.M.

Described from five females, four reared by H. L. Viereck from an aphid gall (Hamamelistes spinosus Shimer?) on witch-hazel (Hamamelis virginiana Linnaeus) at the type locality, and one captured by H. H. Smith at Georgetown, District of Columbia.

Some of the paratypes have the anterior corners of the scutellum and the mesopleura and metapleura below and sides of propodeum more or less reddish, while in $b$ and $c$ the corners of the scutellum have a distinct whitish spot. The Georgetown specimen (paratype $d$ ) is considerably larger, being, with the much distended abdomen $13 \mathrm{~mm}$. in length.

PHTHORIMA SULCICLYPEUS, new species.

Differs from extensor Cushman principally as follows:

Length, $7 \mathrm{~mm}$.; abdomen, $4.5 \mathrm{~mm}$.; antennae (broken);

Vertex shining, punctate; malar space fully as long as basal width of mandible and with a distinct furrow extending from eye to dorsal articulation of mandible; clypeus polished, inflexed from near base, the apical slope with a deep median furrow, emarginate at apex, thorax similar in sculpture, though perhaps less strongly sculptured, and with the metapleurum with simple, sparse punctuation; posterior face of pronotum steeply precipitous; areolet petiolate; nervulus weakly post-furcal; nervellus weakly broken far below middle; compression of abdomen not embracing second tergite, which is fully two-thirds as wide at base as long and strongly scupltured over most of its surface; first tergite not wider at base than at apex and about two-thirds as wide at apex as long.

Black with the same white markings on head and thorax and in addition with the lower cheeks, the sides of scutellum, postscutellum and lower part of mesopleurum also white; hind tibia reddish fuscous at base, white in middle, fuscous at apex, tarsus fuscous except at extreme base of basal joint.

Type locality.-Mount Washington, New Hampshire.

Type.-Cat. No. 22857, U.S.N.M.

One female specimen. 


\section{Subfamily OPHIONINAE.}

\section{Tribe CAMPOPLEGINI.}

\section{Genus ANGITIA Holmgren.}

ANGITIA GALLERIAE, new species.

This species is extremely variable both in size and structure, the extremes being so different that were they compared without the intermediate variations one could not but consider them to be different species. Moreover the extremes run very close to the typical forms of Campoplex Gravenhorst and Sesioplex Viereck. Fortunately the type series consists of a number of specimens, all from the same source at the same time and displaying a gradual variation from one extreme to the other.

The formal descriptison is based entirely on the holotype, while the points of variation are taken up in a separate paragraph. The holotype is selected from near the middle of the series of females.

Female.-Length, $8 \mathrm{~mm}$; antennae, $4.5 \mathrm{~mm}$; ovipositor, $1.75 \mathrm{~mm}$. Temples strongly, convexly receding, occiput broadly concave, eyes sinuately emarginate within; face very slightly narrower than frons; malar space slightly more than half the basal width of mandible; cheeks in front view straight; diameter of lateral ocellus distinctly more than half as long as postocellar line, which is about twice the ocell-ocular line; antennae tapering at apex; head and mesoscutum opaque without distinct punctures; pronotum laterally striate; mesopleurum, mesosternum, and metapleurum minutely, opaquely punctate; sternauli broadly impressed anteriorly; scutellum minutely punctate, subpolished at base; propodeum laterally subpolished coriaceous, medially transversely, irregularly regulose, the carinae distinct and complete except that separating the areola and petiolar areas, the basal area broad at apex; legs rather stout, tibiae more or less compressed, inner calcarium of hind tibia slightly longer than half the basitarsus; areolet large, shortly petiolate, recurrent received at middle; nervulus perpendicular, curved, petiole slightly broader than thick, with a rather deep fovea on each side, the area between this and the base flat, the dorso-lateral carina obsolete; post-petiole slightly though distinctly thicker, longer than broad, the sides weakly curved dorsally with a median and two lateral impressions just behind the spiracles; second tergite three-fifths as wide at base as long, a half longer than third, its sides weakly divergent, the spiracles at about the middle, gastrocoeli distinct, nearly circular, removed from base of segment by about their diameter; ovipositor sheath about one and one-half times as long as first tergite.

Black; mandibles, palpi, and tegulae white; scape and pedicel reddish beneath, antennae otherwise black, hind and middle coxae 
black, the latter reddish beneath; front coxae largely reddish, paler at apex and black at extreme base; front and middle trochanters and apical joint of hind pair white; basal joint of hind trochanter black; hind tibia reddish fuscous, paler above, whitish at extreme base and with black apical and subbasal annuli, this pattern repeated without the black in middle and front tibiae, which are pale yellow above in the middle; hind tarsi fuscous, the joints paler at base but without definite white annuli; other tarsi of similar pattern but paler; femora testaceous, hind femur not black at apex; second tergite distinctly and third faintly reddish laterally.

Of the eight females in the type series four are larger and three smaller than the type, the largest being $9.5 \mathrm{~mm}$. and the smallest $5.5 \mathrm{~mm}$. long.

The smallest (paratype $g$ ) is more slender than the type; the head and thorax are very similar to those of the type, but the median areas of the propodeum are much narrower, the areola being practically acute at base; the venation differs only minutely; the first tergite has the postpetiole strongly swollen above, distinctly longer than wide and without the dorsal impressions; the petiole is scarcely flattened above, as wide as thick, and the lateral foveae are shallow, while the dorso-lateral carinae are obliterated; the second tergite is fully twice as long as wide at base with the gastrocoeli farther removed from the base.

The largest specimen (paratype $a$ ) is somewhat stouter than the type, and differs from it further as follows: The median propodeal areas are wider and slightly concave; the nervulus is distinctly postfurcal and nearly perpendicular; the first tergite is so much depressed that the petiole is much broader than thick, broadly flattened both above and below, and the postpetiole scarcely thicker than the petiole; the lateral fovea very deep, the area in front of it distinctly concave, and the dorso-lateral carina very strong and curving around the fovea; the postpetiole broader than long with the dorsal impressions large and deep; second tergite scarcely a half longer than broad at base, its sides widely divergent, barely a third longer than fourth; ovipositor sheath less than one and one-half times as long as first tergite.

Paratypes $b, c$, and $d$ vary in that order from paratype $a$ to the type, and $e$ and $f$ vary from the type toward paratype $g$. The species is very constant in color, about the only variation being in the extent of red on the tergites.

The male is more slender than the female, has the scape and the front and middle coxae paler, but otherwise is very similar. The only males in the type series are one corresponding to the larger females and one corresponding to the smaller females. The larger (the allotype) is $8.5 \mathrm{~mm}$. long and the smaller (paratype $h$ ) $5.5 \mathrm{~mm}$. 
Host.-Galleria mellonella Linnaeus.

Type locality.-Lansing, Michigan.

Type.-Cat. No. 22858, U.S.N.M.

Described from the above 10 specimens reared by Prof. R. H. Pettit from the host in a honey storage room.

\section{Tribe CREMASTINI.}

Since my revision of the North American Cremastini ${ }^{1}$ was published I have had opportunity to examine the types of the Cresson and Davis species of Cremastus not tabulated in that paper; also several new species of Cremastus have come to hand. Further study of certain other so-called tribes of the Ophioninae convinces me that the tribe Pristomerini of Ashmead and the genus Eiphosoma Cresson should be referred to this tribe. The relation of Eiphosoma to Cremastus was pointed out by Cresson himself in his original description, and he retained it in this position in his Hymenoptera Texana (1872). Roman ${ }^{2}$ goes so far as to include it in the Cremastini. Aside from the possession of the femoral tooth these groups differ in no radical way from Cremastus or the other genera heretofore assigned to the Cremastini. The very elongate form of Eiphosoma and the short, stout form of Pristomerus are both found in Cremastus. The structure of head, thorax, and abdomen differs only in minor details from that of Cremastus, while the venation is practically the same except for the more frequent occurrence of the areolet in Eiphosoma. In general Eiphosoma is very like the typical Cremastus with the clypeus less distinctly separated, the propodeum usually less completely areolated, the areolet more frequently present, and the propodeal "neck" shorter; while Pristomerus is so similar to certain species of the subgenus Zaleptopygus that were it not for the toothed femora they would fall very nicely into that group.

The characters used in my earlier paper to distinguish the Cremastini from the Porizonini do not all apply to both Eiphosoma and Pristomerus, nor, for that matter, to certain new species of Cremastus described below. The abdomen is not always strongly compressed though always distinctly so; and in Eiphosoma and Pristomerus the intercubitus is not always longer than the second abscissa of cubitus, but is always distinct. Xiphosomella Szepligeti is said to have the intercubitus very short or lacking, but it is evidently closely related to Eiphosoma.

The following key to genera is that of my earlier paper with Eiphosoma, Pristomerus, and a new genus added. 
KEY TO NORTH AMERICAN GENERA OF CREMASTINI.

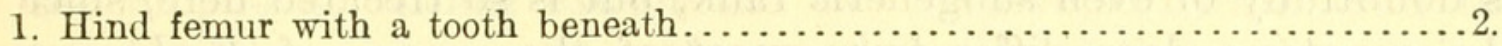

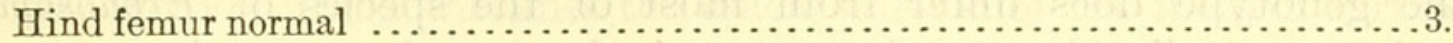

2. Stigma narrow lanceolate, radius at or before middle; petiole with tergite entirely enclosing sternite except at extreme apex and base, its lateral edges fused beneath, the suture obsolete; tooth of hind femur at apical fourth or fifth; compression of abdomen including second tergite; very long, slender species......

Eiphosoma Cresson.

Stigma broad triangular, radius more or less behind middle; first tergite not enclosing sternite; tooth of hind femur at or before apical third; second tergite not compressed; short, stout species.................... Pristomerus Curtis.

3. Areolet present; upper surface of abdomen in female very largely covered by three segments, those beyond third very short......... ()ligotmema, new genus. Areolet absent; segments beyond third not especially ret acted.............

4. (Key to this group already published.)

\section{Genus EIPHOSOMA Cresson.}

Eiphosoma Cresson, Proc. Ent. Soc. Phila., vol. 4, 1865, p. 52, fig. 5.

Xiphosoma (Cresson) Szepligeti, Gen. Ins., fasc. 34, 1905, p. 4.

As stated above Cresson considered this genus to be related to Cremastus. Because of its toothed femora Ashmead ${ }^{1}$ placed it in his tribe Pristomerini; but later, ${ }^{2}$ apparently because of its narrow stigma, he removed it to the Anomalini, where it is obviously discordant. Morley ${ }^{3}$ follows in the footsteps of Ashmead, though calling attention to the obvious relationship to Pristomerus. Szepligeti ${ }^{4}$ erected his subfamily Xiphosominae for this genus and his Xiphosomella, but maintained it in close proximity to the Anomalinae, though calling attention to it under the Pristomerinae. Except Cresson and Roman apparently no one has thought of allying it with Cremastus, all writers ascribing too much importance to the shape of the stigma and the femoral tooth, neither character in the opinion of the writer of more than generic value. Schmiedeknecht, ${ }^{5}$ however, while still using the form of the stigma as his prime character, in his arrangement places the Xiphosomini as Tribe No. 13, the Pristomerini as No. 9, and the Cremastini as No. 10, the Porizonini and Plectiscini falling between the Cremastini and Xiphosomini.

Viereck divided the genus, making Eiphosoma pyratidis Ashmead the type of his genus Brachyxiphosoma. His description consists of the statement of two characters by which it is said to differ from Eiphosoma. Both of these characters, the length of the malar space and the distance to which the propodeum overlies the hind coxae, are very variable and are not always associated in the combination

1 Trans. Amer. Ent. Soc., vol. 23, 1896, p. 191.

$\checkmark$ Proc. U.S. Nat. Mus., vol. 23,1900 , p. 89.

3 Rev. Ichn., pt. 2, 1913, p. 51.

1 Gen. Ins., fasc. 34, 1905, p. 2.

5 Opusc. Ichn., fasc. 18, 1908, p. 1409 . 
indicated by Viereck. Brachyxiphosoma, in the opinion of the writer, is doubtfully of even subgeneric rank, but is so trecated here, since the genotype does differ from most of the species of Eiphosoma in its unusually short malar space, in having the propodeum completely areolated and in having the ground color of the thorax black.

Very long and slender, abdomen very strongly compressed, the compression embracing the second tergite; head very strongly transverse, the temples strongly sloping; eyes and ocelli large; antennae about half as long as body; thorax rather stout; notauli deep anteriorly, becoming obsolete posteriorly; sternauli short but deep; propodeum sloping, more or less completely areolated but usually not completely so; aerolet, if present, oblique and petiolate; legs very slender; hind femur slender at base, with a small tooth beneath at apical fourth or fifth; hind trochanters very long, the two joints subequal in length, basal joint very strongly oblique at apex; abdomen more than twice as long as head and thorax together; first tergite enclosing sternite; second tergite at least as long as first, usually longer; ovipositor less than half as long as abdomen.

The following key includes both the subgeneric and specific characters of the North American species.

KEY TO NORTH AMERICAN SPECIES.

1. Propodeum completely areolated (only the middle portions of the longitudinal carinae sometimes obsolete); malar space less than half as long as basal width of mandible; thorax black with yellow markings (subgenus Brachixiphosoma Viereck) ..................................... pyralidis Ashmead.

Propodeum with only the transverse carinae distinct, longitudinal carinae and frequently the apical carina absent or obsolete; malar space at least half as long as basal width of mandible; thorax yellow with black markings (subgenus Eipho-

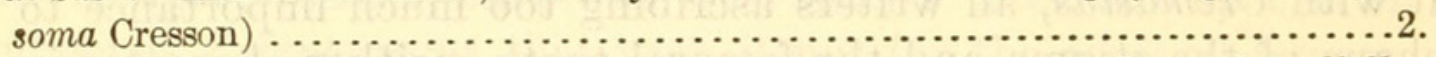

2. Malar space half as long as basal width of mandible; face strongly elevated medially; propodeum and metapleurum separated by a distinct carina..septentrionale Brues.

Malar space distinctly more than half as long as basal width of mandible; face not especially strongly elevated; propodeum and metapleurum separated by a

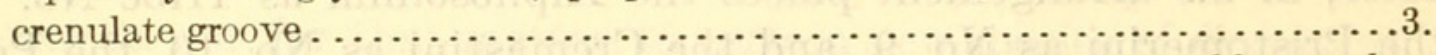

3. Propodeum polished, sparsely punctured laterally and at most weakly rugulose medially, median impression broad; groove separating propodeum and metapleurum shallow and distinctly crenulate, in male subcarinate.texanum Cresson.

Propodeum opaque throughout, median impression narrow; groove separating propodeum and metapleurum deep and indistinctly crenulate...bruesi, new species.

Subgenus BRACHIXIPHOSOMA Viereck.

Brachixiphosoma Viereck, Proc. U. S. Nat. Mus., vol. 42, 1912, p. 147. Type.-Eiphosoma pyralidis Ashmead.

Only two species have been referred to this subgenus. The type is North American. The other, insularis Viereck, is West Indian. It has the malar space only slightly shorter than the basal width of the mandible, while the propodeal "neck" is not appreciably longer 
than that of the type of Eiphosoma. Moreover, insularis lacks all of the propodeal carinae except the two transverse carinae and the basal portion and sometimes the apical portion of the median carinæ. In the present arrangement it would fall in the typical subgenus.

EIPHOSOMA (BRACHIXIPHOSOMA) PYRALIDIS Ashmead.

Eiphosoma pyralidis Ashmead, Trans. Amer. Ent. Soc., vol. 23, 1896, p. 191.

Brachixiphosoma pyralidis (Ashmead) Viereck, Proc. U. S. Nat. Mus., vol. 42, 1912, p. 147.

In addition to the key characters and those mentioned by Ashmead in the original description, the following are perhaps worthy of note. Clypeus in female very broadly rounded, barely half as long as wide, in male subtruncate for its entire width; face medially elevated, slightly narrower than frons; diameter of lateral ocellus subequal to postocellar line and slightly greater than ocell-ocular line; thorax rather densely punctate, the punctures of metapleura smaller; scutellum impunctate; apical carina of propodeum arched in middle; radius before middle of stigma; petiole of areolet shorter than rest of first intercubitus; nervulus interstitial; hind coxae except at apex black.

EIPHOSOMA (EIPHOSOMA) INSULARIS Viereck.

Eiphosoma (Brachixiphosoma) insularis Viereck, Proc. U. S. Nat. Mus., vol. 44, 1913, p. 564.

EIPHOSOMA (EIPHOSOMA) SEPTENTRIONALE Brues.

Eiphosoma septentrionale Brues, Psyche, vol. 18, 1911, p. 22.

There are four females of this species in the National Museum, two from Coleta, Alabama, (H. H. Smith), and one each from College Park, Maryland, and Washington, District of Columbia (both collected by Frederick Knab).

Clypeus broadly subtruncate, strongly convex, two-thirds as long as wide; malar space half as long as basal width of mandible; face elevated medially, equal in width to frons; diameter of lateral ocellus equal to postocellar line and twice as long as ocell-ocular line; thorax sparsely punctate, propodeum and metapleura very obscurely so; propodeum with both transverse carinae, but median carinae developed only before basal and behind apical carinae, sometimes absent in latter position, apical carina medially curved backward; radius before middle of stigma; petiole of areolet equal to or longer, in one specimen much longer, than rest of first intercubitus; nervulus interstitial; hind coxae testaceous and yellow, more or less blackish within.

EIPHOSOMA (EIPHOSOMA) TEXANUM Cresson.

Eiphosoma texanum Cresson, Trans. Amer. Ent. Soc., vol. 4, 1872, p. 176.

Malar space slightly shorter than basal width of mandible; clypeus strongly rounded at apex, two-thirds as long as broad; separation from face weak; face distinctly narrower than frons, not strongly elevated 
medially; ocell-ocular and postocellar lines and diameter of lateral ocellus in female subequal, ocelli in male a trifle larger; thorax sparsely punctate, more densely so on mesoscutum, least densely so on side of propodeum, latter polished medially, apical carina weak and curved backward medially; radius in middle of stigma; petiole of areolet about equal to rest of intercubitus; nervellus postfurcal; hind coxae black and white; black color of thorax more extensive than in following species, covering about as much area as yellow; lateral black mark of propodeum reaching nearly to apex and embracing the spiracle.

\section{EIPHOSOMA (EIPHOSOMA) BRUESI, new species.}

Allied to texanum Cresson and runs to that species in Brues' key ${ }^{1}$ to the species of the genus; but differs principally as follows from specimens of that species in the United States National Museum:

Female.-Length, $10 \mathrm{~mm}$; antennae, $4.5 \mathrm{~mm}$.; ovipositor, $2.5 \mathrm{~mm}$.

Malar space distinctly shorter than basal width of mandible; face only slightly narrower than frons; ocelli larger, being nearly twice as long as ocell-ocular line; thorax and propodeum rather densely punctate; yellow color of thorax more extensive than black, lateral mark of propodeum small, not extending nearly to apex and confined to depression between propodeum and metapleurum, interrupted or constricted at spiracle.

Agrees with above description of texanum otherwise.

Type locality.-Granger, Texas.

Type.-Cat. No. 22859, U.S.N.M.

Described from two females, the type taken May 20, 1895, and determined by Ashmead as texanum. The paratype is labeled merely "Hunter No. 2505 P. X."

The paratype differs from the type but very little, the lateral mark on the propodeum being slightly larger, and the areolet of the right wing being entirely lacking while that of the left wing is very small and poorly defined.

Named in honor of Dr. C. T. Brues, of the Bussey Institution, Cambridge, Massachusetts.

\section{Genus PRISTOMERUS Curtis.}

In all published arrangements of the tribes of the Ophioninae the tribe Pristomerini has been placed next to the Cremastini and separated from that tribe only by the character of the toothed hind femora. Schmiedeknecht ${ }^{2}$ mentions several other characters, principally of venation, in his description of the tribe, all of which are to be found in one or another of the genera that he places in the Cremastini. In his tribal key he modified the femoral character to 
include Demophorus Thomson, said to have the femora incrassate but not toothed.

Mostly rather stout species, the compression of the abdomen not embracing second tergite; head strongly transverse, temples sloping; eyes and ocelli large; antennae somewhat more than half as long as body; thorax stout; notauli distinct anteriorly, obsolete posteriorly; sternauli obsolete; propodeum rounded; completely areolated; areolet very rarely defined, if so oblique and petiolate; hind femur more or less swollen and with a more or less distinct tooth beneath situated from shortly behind middle to apical third, frequently followed by a row of denticles; hind trochanters short; abdomen less than twice as long as head and thorax together; first tergite longer than second, not enclosing sternite; ovipositor more than half as long as abdomen.

The following key includes both the subgeneric and specific characters of the North American species. Ashmead's genus Pristomeridea. based on the size and position of the femoral tooth, the shape of the areola, and the form of the nervellus must be considered as a synonym of Pristomerus, since all of these characters are subject to great variation. Neopristomerus Viereck is so much more closely allied to Pristomerus than to any of the other genera of the tribe as here treated that it must be considered subgeneric. Moreover, the two characters given by Viereck are not always associated. The eyes throughout Pristomerus vary greatly in their relation to each other, especially in the male. The obsolete cubitus and subdiscoideus do not furnish an absolute character, for some species have these veins thick for a short distance and then rather suddenly weakening, though still distinct to the apex of the wing. The species dubia Brues, coloradensis Brues, and pacificus Cresson are not represented in the material studied, and their insertion in the key is based on the characters ascribed to them by Brues ${ }^{1}$ in his key to species.

KEY TO NORTH AMERICAN SPECIES.

1. Wings with an areolet; second discoidal cell very narrow at base; ovipositor not sinuate near apex (subgenus Areolopristomerus Cushman)............

Wings without an areolet; third discoidal cell not especially narrow at base;

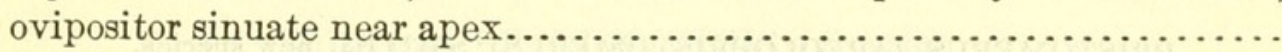

2. First joint of flagellum longer than second; propodeum not excavated behind; second tergite shorter than first, striate throughout............

smithi, new species.

First two joints of flagellum equal in length; propodeum excavated behind; second tergite as long as first, shining on basal third........... dubia (Brues).

3. Cubitus and subdiscoideus extending to margin of wing, former straight or slightly curved at base, but the base not directed sharply forward; second abscissa of cubitus longer than intercubitus (subgenus Pristomerus Curtis).

Cubitus and subdiscoideus not extending much beyond recurrent, being represented beyond by folds or streaks; second abscissa of cubitus shorter than intercubitus (subgenus Neopristomerus Viereck)................. 
4. Head in front view not or barely wider than long, seen from above with temples strongly rounded; eyes in male subparallel within, ocelli not especially large; wings stained with brown; thorax largely black with scutellum red ............................ fuscipennis, new species.

Head in front view distinctly wider than long, seen from above with temples weakly rounded and much narrowed; eyes in male convergent above, ocelli very large; wings hyaline; thorax largely red, or if black the scutellum is also black.

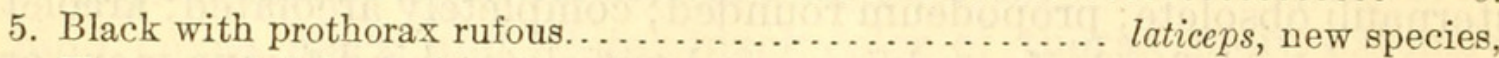

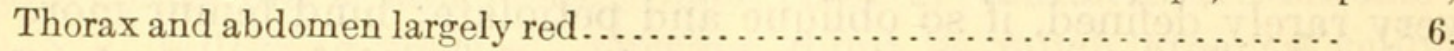

6. Eye fully a third longer than wide; ocelli large, lateral ones in female closer together than their greatest diameter, in male touching the eyes; malar space barely half as long as basal width of mandible... ocellatus, new species.

Eye barely a fourth longer than wide; ocelli smaller, lateral ones in female removed from each other by their diameter, in male distinctly removed from eyes; malar space much more than half as long as basal width of mandible.

7. Clypeus broadly truncate; radius weakly curved at apex; base of third discoidal cell nearly as long as apical abscissa of discoideus (a larger

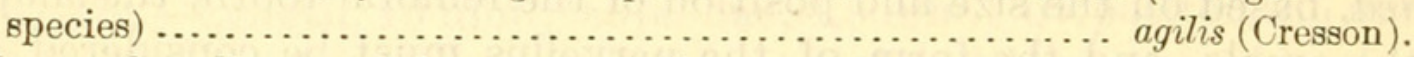

Clypeus broadly rounded at apex; radius strongly curved at apex; base of third discoidal cell barely half as long as apical abscissa of discoideus (a very small species)........................ minutus, new species.

8. Areola distinctly longer than broad, apical abscissa of subdiscoideus distinct at base . . . . . . . . . . . . . . . . . . . . . . . . . . . . . .

Areola scarcely longer than broad; apical abscissa of subdiscoideus obso-

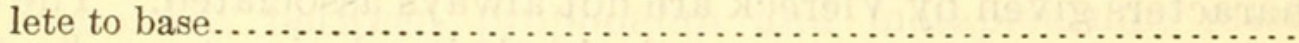

9. Body entirely ferruginous, at most with the tergites blackish basally................................ melleus, new species.

Thorax at least partly black or piceous.............. appalachianus Viereck.

10. Hind coxae almost entirely black; wings clear hyaline; second discoidal cell strongly contracted at base........................ coloradensis Brues.

Hind coxae entirely ferruginous; wings tinged with yellow; second discoidal cell less strongly contracted at base................... pacificus Cresson.

AREOLOPRISTOMERUS, new subgenus.

Differs from Pristomerus Curtis principally in the possession of the areolet and the very narrow base of the second discoidal cell. Type.-Pristomerus (Areolopristomerus) smithi Cushman.

PRISTOMERUS (AREOLOPRISTOMERUS) SMITHI, new species.

Female.-Length, $8 \mathrm{~mm}$.; antennae, $5 \mathrm{~mm}$.; ovipositor, $2.5 \mathrm{~mm}$.

Head in front view much wider than long, in dorsal view strongly transverse, the temples nearly flat and very narrow; face very narrow, two-thirds as wide as length of eye; eyes large, parallel within, but slightly sinuate opposite antennae; malar space two-thirds as long as basal width of mandible; diameter of lateral ocellus subequal to ocell-ocular line and slightly longer than postocellar line; antennae slightly below middle of eyes, first flagellar joint longer than second; thorax mostly opaque shagreened with weak scattered punctures; pronotum polished laterally; mesopleural impression striate; scutel- 
lum subpolished; propodeum not excavated behind, opaque shagreened, areola pentagonal, twice as long as wide, costulae at anterior third, spiracles, small oval; legs slender, femoral tooth at apica third, very small, denticles obsolete, calcarium of hind tibia reaching nearly to middle of basitarsus; abdomen rather slender; second tergite nearly as long as first, three times as long as wide at base, striate, as are also postpetiole and base of third; other tergites polished.

Pale rufo-fulvous; face, clypeus, mouth parts, scape and pedicel, and legs largely stramineous; first tergite in middle, second and third, at base, and fourth to sixth dorsally piceous; basal joint of hind trochanter on inner side, tibia at base and apex, and tarsus except major part of first joint fuscous; wings hyaline, stigma black with anterior margin pale.

Type locality.-Pyziton, Clay County, Alabama.

Other localities. Coleta, Alabama, and College Station, Texas.

Type.-Cat. No. 22860, U.S.N.M.

Described from three females, the two Alabama specimens collected by the late H. H. Smith, for whom the species is named, and the Texas specimen by Nathan Banks.

Paratype $a$ has the body and the hind femora and coxæ more rufous and the femora slightly infuscate inside.

PRISTOMERUS (AREOLOPRISTOMERUS) DUBIA (Brues).

Pristomeridia (?) dubia Brues, Psyche, vol. 18, 1911, p. 24, female, pl. 6, figs. 9 and 10.

This species, which Brues doubtfully placed in Pristomeridia, is evidently very closely related to smithi Cushman. A comparison of Brues's description with smithi shows the following differences: First, two joints of flagellum equal in length; propodeum excavated behind, basal area quadrangular; spiracles round; second tergite as long as first, shining on basal third; wings slightly infuscated apically; posterior femora largely piceous.

The unique type is from Blue Hills, near Boston, Massachusetts.

Subgenus PRISTOMERUS (Curtis).

Pachymerus Gravenhorst, Ichn. Eur., vol. 3, 1829, p. 721 (part).

Pristomerus Curtis, Brit. Ent., vol. 13, 1836, p. 624.

Pristomeridea Ashmead, Proc. U. S. Nat. Mus., vol. 23, 1900, p. 100.

PRISTOMERUS (PRISTOMERUS) FUSCIPENNIS, new species.

Female.-Length, $5.0 \mathrm{~mm}$; antennae, $3.5 \mathrm{~mm}$.; ovipositor, $2.5 \mathrm{~mm}$. Head in front view barely wider than long, seen from above with temples strongly rounded, opaque shagreened, face sparsely punctate; eyes parallel within; clypeus convex, broadly truncate at apex, two-thirds as long as broad; malar space nearly as long as basal width of mandible; ocelli in a nearly equilateral triangle; diameter 
of lateral ocellus, postocellar and ocell-ocular lines subequal; thorax dorsally opaque, mesoscutum shagreened and punctate; pronotum polished, rugulose in impressions; mesopleura and metapleura subpolished and punctate, punctures on mesopleura rather coarse and well separated; fossa in front of scutellum deep, the scutellum nearly carinate in front; propodeum densely punctate dorsally and laterally, rugose posteriorly, areola pentagonal, somewhat more than twice as long as wide, costulae very near cephalic end; femoral tooth short, at about apical two-fifths, denticles absent, the femur slightly less than a third as thick as long; stigma nearly two-thirds as wide as long, radius at apical third; nervulus distinctly postfurcal; second and third abscissae of discoideus equal in length; nervellus slightly broken, weakly inclivous; postpetiole and second tergite finely striate, others obscurely shagreened, second nearly twice as long as wide at base, the sides widely divergent, ovipositor four-fifths as long as abdomen.

Head black, face, orbits, cheeks, clypeus, and mandibles fulvous; antennae black, scape and pedicel fulvous beneath; thorax black, prescutum and scutellum red, notauli faintly reddish; tegulae and wing bases yellow; wings infumate hyaline; legs fulvo-testaceous, hind trochanters dorsally at base piceous, second joint and apex of femur yellow, tibia and tarsus fuscous, tibia pale in middle, calcaria yellow; abdomen piceous, all tergites except first yellow at apex and more reddish laterally, first with postpetiole reddish.

Male.-Differs from the female in having the tergites relatively narrower and the hind femur stouter, with the tooth larger and at the apical third and the denticles well developed.

Type locality.-Onaga, Kansas.

Other localities.-Chain Bridge, District of Columbia; Oswego, New York.

Type.-Cat. No. 22861, U.S.N.M.

Described from six specimens, the type and allotype from the type locality (Crevecoeur); a female, paratype $a$, from Chain Bridge, District of Columbia, September 15, 1912 (J. R. Malloch); and three males, paratypes $c, d$, and $e$, from Oswego, New York, August 27, 1896.

All of the paratypes have the face more or less marked with blackish. The color of the abdomen varies somewhat, especially that of the first tergite which varies from entirely red to entirely piceous.

\section{PRISTOMERUS (PRISTOMERUS) OLAMONUS Viereck.}

Pristomerus olamonus Viereck, Hym. Conn., 1917, p. 274.

Described only by color and the length of the ovipositor, it can not be placed in the key to species. What characters are given by Viereck are very suggestive of fuscipennis Cushman, except that the color pattern is brown rather than fulvous and reddish. 


\section{PRISTOMERUS (PRISTOMERUS) LATICEPS, new species.}

Differs from fuscipennis principally as follows:

Female.-Length, $5 \mathrm{~mm}$; antennae, $4 \mathrm{~mm}$.; ovipositor, $3 \mathrm{~mm}$.

Head in front view strongly transverse, seen from above with temples flat and very narrow; inner margins of eyes slightly concavely curved; malar space much narrower than mandible at base; diameter of lateral ocellus nearly twice as long as ocell-ocular line, which is subequal to postocellar line; mesoscutum opaque shagreened but impunctate; thorax laterally and propodeum dorsally very sparsely punctate, subopaque; areola hardly twice as long as wide, costulae at cephalic third; hind femur barely one-fourth as thick as long, tooth long, denticles distinct; nervulus interstitial; second tergite distinctly more than twice as long as wide at base, its sides weakly divergent; ovipositor as long as abdomen.

Head black, apex of clypeus piceous, mandibles yellow; thorax black with only pronotum red; front and middle legs pale testaceous, coxae and trochanters stramineous; hind coxae rufous, piceous within, trochanters pale, basal joint piceous within, tibia reddish piceous, yellow at apex, tibia and tarsus fuscous, former pale in middle and with calcaria white; wings hyaline; abdomen entirely piceous except yellowish or whitish margins of all tergites and basal angles of third.

Type locality.-Falls Church, Virginia.

Type.-Cat. No. 22862, U.S.N.M.

Described from two females, the type taken June 7, 1914, by William Middleton, and the paratype at the same locality July 4, 1913, by Frederick Knab.

The paratype is slightly smaller than the type, but otherwise practically identical with it.

\section{PRISTOMERUS (PRISTOMERUS) OCELLATUS, new species.}

In the female this species is very much like agitis (Cresson), but in male the very large ocelli and strongly divergent eyes render it very distinct from any of the described North American species.

Female.-Length, $8 \mathrm{~mm}$; antennae, $5 \mathrm{~mm}$.; ovipositor, $4 \mathrm{~mm}$.

Head in front view wider than long; face slightly narrower than frons; eyes slightly arcuate opposite antennae, fully a third longer than wide; malar space little more than half as long as basal width of mandible; clypeus subtruncate at apex; lateral ocelli closer toether than their greatest diameter; pronotum polished; mesoscutum opaque shagreened, rather densely punctate medially, lateral lobes subpolished; scutellum polished; mesopleurum punctate opaque below, polished above, the oblique impression obliquely striate in anterior end; propodeum punctate dorsally and laterally, transversely rugulose posteriorly, areola narrow pentagonal, costulae at anterior third; hind femur stout; tooth large, not far beyond middle, denticles 
distinct; longer hind calcarium reaching only one-third length of basitarsus; abdomen polished, postpetiole, second tergite, and base of third striate; second tergite nearly as long as first, twice as long as basal width.

Ferruginous; mandibles, palpi, tegulae, petiole, and apices of second and following tergites yellow; occiput (largely), ocellar triangle, pronotum dorsally, prescutum anteriorly, propodeum basally, postpetiole, second and third tergites largely, and others dorsally blackish or piceous; front and middle legs pale testaceous, their coxae and trochanters stramineous; hind legs darker, coxae, trochanters and femora within, tibiae at base and apex, and tarsi except at base fuscous, femur at apex, tibia in middle and tarsus basally whitish; wings hyaline, veins and stigma black.

Type Tocality.-Pyziton, Clay County, Alabama.

Other localities.-Langdale, Chambers County, Alabama; Lexington, Kentucky; Marshall Hall, Maryland; North East, Pennsylvania; Lawrence, Kansas.

\section{Type.-Cat. No. 22863 , U.S.N.M.}

The male differs principally in having the ocelli touching the eyes and the latter very strongly divergent below; the thorax polished and practically impunctate; the hind femur very stout with the large tooth in the middle and the denticles conspicuous.

Described from three females - two from the type locality and one from Langdale, Alabama - all collected by H. H. Smith; and four males, one from each of the last four localities mentioned. The Maryland specimen, which is the allotype, is said to have been reared from stems of Polymnia uvedatia infested by the weevil Rhodobaenus 18-punctatus.

PRISTOMERUS (PRISTOMERUS) AGILIS (Cresson).

Porizon? agilis Cresson, Trans. Amer. Ent. Soc., vol. 4, 1872, p. 175, female.

Pristomerus euryptychiae Ashmead, Trans. Amer. Ent. Soc., vol. 23, 1896, p. 192.

Pristomeridia agilis (Cresson) AshmeAd, Proc. U. S. Nat. Mus., vol. 23, 1900, p. 100.

The types of both Cresson's and Ashmead's names are in the United States National Museum, the latter without the abdomen. In addition there are many specimens of both sexes ranging from Texas and Kansas through Alabama, Kentucky, West Virginia, District of Columbia, Maryland, and Massachusetts. The position of the femoral tooth varies with size, the smaller the tooth the nearer to the apex. In no case except in the male, is it nearly at the middle. There is considerable variation also in the length of the ovipositor and the relative length and width of the second tergite.

Many of the specimens have been reared by A. B. Gahan at College Park, Maryland, probably from Acrobasis caryae; by S. W. Bilsing, at College Station, Texas, from Acrobasis caryaevorella; by J. D. 
Mitchell at Victoria, Texas, from pecan probably on an Acrobasis species; at Dallas, Texas, under Hunter No. 1486; and in Massachusetts from lepidopterous larvae on cranberry. Ashmead's type was reared from Euryptchia saligneana in District of Columbia.

PRISTOMERUS (PRISTOMERUS) MINUTUS, new species.

Female.-Length, $4 \mathrm{~mm}$; antennae, $3 \mathrm{~mm}$; ovipositor, $2 \mathrm{~mm}$.

Much smaller than agilis and differing otherwise principally by the key characters. Compared with the above description of ocellatus differs as follows: eyes broader, not a third longer than wide; malar space nearly as long as basal width of mandible; clypeus rounded at apex; diameter of lateral ocellus and postocellar line subequal; mesoscutum subpolished and densely punctate throughout; mesopleurum polished, punctate below, the striation perpendicular; areola broad; hind femur hardly stout, tooth very small and far beyond middle, denticles absent; second tergite distinctly shorter than first, nearly three times as long as wide at base; third not striate at base.

Head piceous, orbits ferruginous; clypeus, mandibles, and scape and pedicel yellowish; thorax, including propodeum, largely piceous, pronotum, mesoscutum, and scutellum ferruginous; wings hyaline, venation brown; legs stramineous, hind femur dull testaceous, tibia fuscous at base and apex, tarsal joints fuscous, pale at base; abdomen largely reddish piceous, paler at sides.

Type locality.-Los Angeles County, California.

Type.-Cat. No. 22864, U.S.N.M.

Described from one female reared by D. W. Coquillett from a cecidomyid gall on juniper.

\section{Subgenus NEOPRISTOMERUS Viereck.}

Neopristomerus Viereck, Proc. U. S. Nat. Mus., vol. 43, 1912, p. 592.

PRISTOMERUS (NEOPRíSTOMERUS) MELLEUS, new species.

Female.-Length, $6 \mathrm{~mm}$; antennae, $4.5 \mathrm{~mm}$.; ovipositor, $2.5 \mathrm{~mm}$.

Head broader than long; face slightly narrower than frons, polished, sparsely punctate; clypeus strongly rounded at apex, malar space slightly longer than basal width of mandible, ocelli distinctly narrower than either ocell-ocular or postocellar line; temples convex, opaque, as is also the vertex; mesoscutum opaque, coarsely punctate; pronotum polished, punctate in lower angle; mesopleura, metapleura, and propodeum punctate, last striate posteriorly; areola hexagonal, slightly more than one and one-half times as long as wide, costulae at about anterior two-fifths; stigma rather narrow, barely half as wide as long; hind femur slender, tooth at apical third, denticles obsolete, longer calcarium more than a third as long as basitarsus; abdomen polished; second tergite much shorter than first, about two and onehalf times as long as wide at base, only slightly wider at apex. 
Body pale fulvous with small dark markings on occiput and on tergites beyond first; legs stramineous, hind femur slightly testaceous, tibia at base and apex and tarsus fuscous; wings hyaline.

Male.-Differs from female practically only by the secondary sexual characters of more slender abdomen and stouter hind femur with larger tooth placed nearer the middle and distinct denticles. The ocelli are not noticeably larger than in female.

Type locality.-Washington, District of Columbia.

Other localities.-Raleigh, North Carolina (allotype) and Columbia, South Carolina.

Type.-Cat. No. 22865, U.S.N.M.

Described from one female and two males. The allotype was received from Gerald McCarthy and reared from a Gelechia on tobacco under Bureau of Entomology No.70880 ; and the paratype by P.Luginbill from Elasmopalpus lignosellus, under Webster No. 9742.

The paratype is brighter in color throughout and the legs testaceous rather than stramineous.

\section{PRISTOMERUS (NEOPRISTOMERUS) APPALACHIANUS Viereck.}

Pristomerus appalachianus Vieneck, Trans. Kans. Acad. Sci., vol. 19, 1903-1904, p. 298 , female, male.

Pristomerus texanus Ashmead, in Sanderson, Bur. Ent. Bull. 57, 1906, p. 36 (nomen nudum).

Neopristomerus appalachianus (VIEREck), Proc. U. S. Nat. Mus., vol. 43, 1912, p. 592.

This species is represented in the national collection by a considerable series, mostly of the variety dorsocastaneus Viereck, from Kansas, Oklahoma, Texas, New Mexico, and Louisiana. It is reared from such hosts as Prodenia species, Caradrina exigua, Loxostege species, and Laphygma frugiperda. There is considerable variation in size and color.

The variety dorsocastaneus was described in the same paper as the typical form and transferred to Neopristomerus also in the same paper.

OLIGOTMEMA, new genus.

The following description is based only on the female, the male being unknown. Has somewhat the appearance of a small Hemiteline and also of Canidia in the Campoplegini; but the very short basal abscissa of radiella, separated clypeus, and closed areola indicate its Cremastine affinities. In the very short radial cell it resembles the Porizonini, but the angle of the radius is not acute, the apical abscissa of radius curves forward toward the metacarpus, the basal vein is not thickened at its stigmal end, and the ovipositor is straight or slightly decurved.

From all the other genera here referred to the Cremastini it differs in the form of the abdomen. This is short, deep, and broad, broadest at apex of second tergite, which is beyond the middle of the abdomen 
whence it narrows rapidly to the acute apex, the dorsal surface being largely composed of three tergites, the others much retracted. From most of the genera it differs in the possession of an areolet, which is large and in form nearly like that of Mesochorus.

Form short and thick, with abdomen barely as long as head and thorax together; antennae nearly as long as body; head, thorax, and propodeum opaque; palpi normal; propodeum short, precipitous behind, hardly extending over hind coxae; wings ample, broad; stigma broad, radius originating beyond middle; radial cell short, not longer on metacarpus than stigma, radial angle slightly obtuse, second abscissa of radius curving slightly forward at distal end; areolet large quadrate, second intercubitus somewhat longer than other three sides, which are subequal; second discoidal cell very short and broad; nervulus interstitial; nervellus perpendicular, weakly broken below middle; abdomen polished; petiole wider than thick, with distinct lateral foveae, edges of tergite distant, not enclosing sternite; postpetiole flattened, several times broader than thick; spiracles at apical two-fifths of segment; second tergite much broader at apex than at base, gastrocoeli indistinct, spiracles before middle; legs long, hind femur reaching nearly to apex of abdomen, femora and tibiae stout, tarsi slender.

Type.-Oligotmema prima Cushman.

OLIGOTMEMA PRIMA, new species.

Female.-Length, $4 \mathrm{~mm}$; antennae, $3 \mathrm{~mm}$; front wing, $3 \mathrm{~mm}$.

Head transverse, temples convexly receding; occiput shallowly concave; eyes straight and parallel within, as long as width of face; diameter of ocellus half as long as postocellar line, which equals ocellocular line; entire head including clypeus and temples opaque; clypeus strongly convex and strongly rounded at apex; malar space nearly as broad as basal width of mandible; teeth of mandible equal in length; pronotum obliquely striate below; mesoscutum as wide as long, opaque with minute separated punctures; scu-

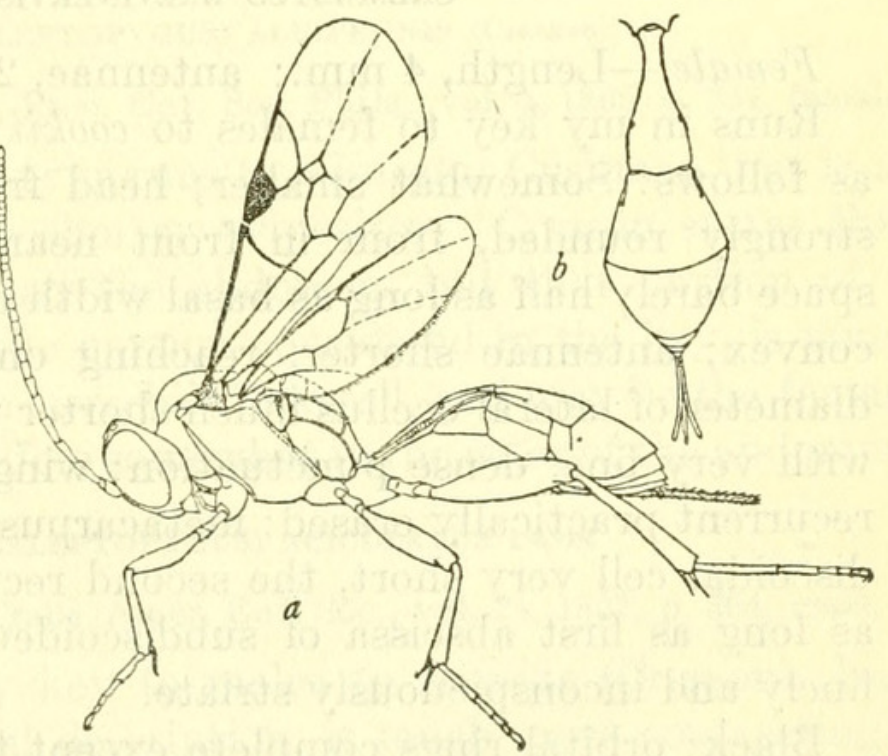

Fig. 1.-Oligotmema prima cushman. (a) lateral view. (b) DORSAL VIEW OF ABDOMEN. tellum sculptured like mesoscutum; thorax laterally and propodeum more strongly punctured; areola as wide as long; petiolar area occupying more than half the length of propodeum, transversely striato- 
punctate; postpetiole and second tergite at base obsoletely, longitudinally aciculate; first tergite much longer than second, which is slightly longer than third; remaining tergites together much shorter than third; ovipositor sheath barely as long as first tergite.

Black; antennae dark brown, paler beneath toward base; mandibles, palpi, tegulae, and front and middle coxae pale brownish; hind coxae and tarsi darker; legs otherwise testaceous; wings hyaline, venation of front wing dark brown, that of hind wing pale brown; abdomen piceous black, tergites narrowly paler at apex.

Type locality.-Colorado.

Type-Cat. No. 22866, U.S.N.M.

Described from three females collected by C. F. Baker.

\section{Genus CREMASTUS Gravenhorst.}

\section{Subgenus CREMASTUS Gravenhorst.}

CREMASTUS FERRUGINEUS Davis.

Cremastus ferrugineus DAvis, Trans. Amer. Ent. Soc., vol. 24, 1897, p. 364, female.

The type of this species runs in my key to females to graciliventris Cushman, but differs from that species as follows: Lateral ocellar, postocellar, and ocell-ocular lines in ratio of $1: 2: 1$, ocelli 1 ; occipital and ocellar black spots confluent, latter extended down front to base of antennae; a $V$-shaped spot, with base at middle of propodeum and a branch each side of scutellum black; wings hyaline.

This species was tabulated in the earlier paper, but the specimen used in keying out the species was evidently incorrectly determined.

CREMASTUS BREVINERVIS, new species.

Female.-Length, $4 \mathrm{~mm}$; antennae, $2.5 \mathrm{~mm}$; ovipositor, $1.5 \mathrm{~mm}$.

Runs in my key to females to cookii Weed, from which it differs as follows: Somewhat smaller; head from above with temples less strongly rounded, from in front nearly transversely oval; malar space barely half as long as basal width of mandible; clypeus strongly convex; antennae shorter, reaching only to apex of first tergite; diameter of lateral ocellus much shorter than ocell-ocular line; thorax with very fine, dense punctuation; wings with reins beyond second recurrent practically erased; metacarpus shorter than stigma; second discoidal cell very short, the second recurrent much more than half as long as first abscissa of subdiscoideus; second tergite only very finely and inconspicuousiy striate.

Black; orbital rings complete except for short interruption at top of eye; cheeks, malar space, clypeus, and mandibles yellow; scape and pedicel but not basal joints of flagellum yellow below; legs as a whole darker, but coxae not at all black at base; front and middle coxae and trochanters white, hind pair red; hind femur at apex and tibia, as 
well as middle tibia, beneath fuscous; all tarsi white, apical joint fuscous; wing veins and stigma fuscous; first tergite rufous, others blackish with lateral and apical margins more or less yellow.

Type locality.--Globe, Arizona.

Type-Cat. No. 22148, U.S.N.M.

One specimen taken on Thurberia thespesioides by C.H.T. Townsend.

CREMASTUS BRUNEICEPS, new species.

Female.-Length, $6 \mathrm{~mm}$; antennae, $4 \mathrm{~mm}$.; ovipositor, $2 \mathrm{~mm}$. Runs in my key to females to plaitynotae Cushman and agrees with all key characters, but differs from that species as follows: Eyes very slightly convergent below; clypeus less strongly convex and rather broadly rounded at apex; face opaque; diameter of ocelli fully twothirds as long as postocellar line; pronotum laterally shining, finely regulose; petiolar area densely, transversely regulose; second tergite distinctly more than four times as long as wide at base.

Head brownish, without distinct markings; seape, pedicel, and basal joint of flagellum pale below; thorax entirely ferruginous; propodeum with a dusky spot in basal middle; legs as in platynotae, except that the contrast in color of coxae and trochanters and femora is less; abdomen largely ferruginous, tergites except first more or less fuscous.

Type locality.-Washington, District of Columbia.

Type.-Cat No, 22149, U.S.N.M.

One female taken by H. L. Viereck, July 2, 1910.

Subgenus ZALEPTOPYGUS Viereck.

CREMASTUS (ZALEPTOPYGUS) ALBIPENNIS (Cresson).

Porizon albipennis Cresson, Proc. Ent. Soc. Phila., vol. 4, 1865, p. 287, female.

In my key to females the type runs to bitineains Cushman, but is at once distinguishable by its shorter ovipositor. Cresson states that the ovipositor is longer than the abdomen, but that portion of it that is exserted, which is the portion considered in the key, is much shorter. It looks more like viereckii Cockerell, and may be the female of that species, though it differs somewhat in the color of the abdomen.

\section{CREMASTUS (ZALEPTOPYGUS) ACICULATUS Davis.}

Cremastus aciculatus DAvis, Trans. Amer. Ent. Soc., vol. 24, 1897, p. 364, male.

This species runs in my key to males to retiniae (Cresson), but, as indicated by the original description, is much more contrastingly colored, the thorax generally black with the pronotum red. In this character it is more closely allied to rosae Cushman and plesius Cushman, both of which are known only in the female, and is very possibly the male of one of these. 


\section{CREMASTUS (ZALEPTOPYGUS) GRANULATUS Davis.}

Cremastus granulatus Davis, Trans. Amer. Ent. Soc., vol. 24, 1897, p. 365, female, male.

In the type series of this species, consisting of four females and one male, there are apparently three species confused. The female bearing the name label and further labeled "Ag. Coll. Mich., 6.8.92$209, "$ is hereby designated as the holotype. This specimen runs in the key to similis Cushman and differs from the description of that species only in the second tergite not being parallel-sided but slightly divergent, and in the abdomen being entirely black. Comparison of the types would undoubtedly show other differences.

\section{CREMASTUS (ZALEPTOPYGUS) NEMORALIS Davis.}

Cremastus nemoralis Davis, Trans. Amer. Ent. Soc., vol. 24, 1897, p. 364, female, male.

In my key to females the type runs to the second alternate of couplet 20 on account of its nearly black hind coxae, but it is really more closely allied to the group of species under the first alternate. In this placing it runs on most of the characters to simitis Cushman, from which it differs as follows: Petiolar area much broader than areola, latter distinctly more than half as broad as long; first tergite longer than second; second tergite broader, sides weakly divergent; ovipositor longer than abdomen; abdomen black throughout; scutellum black; hind legs mostly dark, coxae and femora piceous, tibiae and tarsi fuscous, trochanters, apices of coxae, and base and apex of femur whitish.

The male runs to the second alternate of couplet 9 , but is more closely allied to the species falling under the first alternate, where it agrees best with tetralophae Cushman. Differs from female in having scutellum more or less reddish; yellow color of pronotum extending into notauli; middle tergites somewhat reddish; eyes and ocelli larger but not extremely large; diameter of lateral ocellus equal to postocellar line, which is a half longer than ocell-ocular line; face entirely yellow.

\section{CREMASTUS (ZALEPTOPYGUS) ORBUS (Davis).}

Leptopygus orbus Davis, Trans. Amer. Ent. Soc., vol. 24, 1897, p. 365, female, male.

Both sexes run in my key to obereae Viereck, differing in the key characters only in having the wings hyaline.

The two following new species are remarkable for the very short, stout thorax with the mesoscutum broader than long and the areola hardly half as long as the petiolar area. On these characters and the pectinate claws they run in Szepligeti's key ${ }^{1}$ to Celor Semenow, 
but differ in having the scutellum flat without lateral carinae and not declivous behind, the areola hexagonal rather than quadrate, and the sixth tergite not excised. In my key to females both run out at couplet 25 , but agree with neither alternate, but better with tetralophae Cushman. From the key characters applying to that species both differ in having the ovipositor sheath much less than twice as long as the first tergite.

CREMASTUS (ZALEPTOPYGUS) OBESUS, new species.

Female.-Length, $5.25 \mathrm{~mm}$; antennae, $4 \mathrm{~mm}$.; ovipositor, $2.5 \mathrm{~mm}$.

Head from above fully twice as broad as long, with temples narrow, weakly convex, and sharply sloping, from in front but little wider than long; eyes large, much longer than width of face, parallel within; diameter of lateral ocellus equal to ocell-ocular line; malar space scarcely half as long as basal with of mandible; clypeus strongly arched basally, broadly rounded at apex, weakly convex; head minutely shagreened, interspersed on face with scattered minute punctures; thorax very short and stout, sculpture fine shagreening interspersed with minute punctures; mesoscutum wider than long, notauli weak except anteriorly; scutellum flat; propodeum short, steeply declivous nearly from base, shagreened, petiolar area transversely striate; areola hexagonal, nearly as broad as long, barely half as long as petiolar area; legs slender, longer spur of hind tibia reaching beyond middle of basitarsus; claws pectinate; wings broad, basal vein and second abscissa of radius straight; discocubital cell hardly a half longer than basal vein, second recurrent distinctly more than half as long as basal abscissa of subdiscoideus; compressed portion of abdomen fully a fourth as deep as entire length of abdomen; first tergite comprising distinctly more than a third of the total length and distinctly longer than dorsal length of propodeum, dorsolateral carina distinct from spiracle to base, postpetiole very finely striate; second tergite but very little more than half as long as first, slightly more than twice as long as basal width, finely longitudinally striate; third tergite striate at base, otherwise, together with remaining tergites, shining; ovipositor sheath distinctly more than a half longer than first tergite.

Dark ferruginous; occiput, vertex, and frons blackish; inner orbit above antenna, lower cheek, mandibles, and clypeus yellow; antennae black, paler toward base especially beneath; pronotum and scutellum slightly paler than surrounding areas; legs pale testaceous, front and middle coxae and trochanters stramineous; hind tibiae infuscate especially at apex; hind and middle tarsi white, darker at apex; tibial spurs white; wings hyaline, veins and stigma dark brown; postpetiole, second tergite largely, and third at base brownish, postpetiole and second tergite yellowish at apex. 
Type locality.-Hyattsville, Maryland.

Type.-Cat. No. 22150, U.S.N.M.

Described from two females collected September 1, 1912, by J. R. Malloch.

The paratype differs in lacking entirely the black on the head and in having all the tergites more or less brownish.

CREMASTUS (ZALEPTOPYGUS) LATITHORAX, new species.

Female.-Length, $5.25 \mathrm{~mm}$; antennae, $4 \mathrm{~mm}$; ovipositor, $1.5 \mathrm{~mm}$.

Of same size and form as obesus, but at once distinguishable by the shorter ovipositor, and differing from that species only as follows: Diameter of lateral ocellus slightly shorter than ocell-ocular line; petiolar area not striate; second recurrent vein barely longer than first abscissa of subdiscoideus; second tergite distinctly more than half as long as first; ovipositor sheath barely a half longer than first tergite.

Paler throughout; head less contrastingly colored, the black replaced by fuscous; antennae brown; venation light brown.

Type locality.-Sabinal, Texas.

Type.-Cat. No. 22151, U.S.N.M.

One female collected by F. C. Pratt and labeled "Hunter No. 2106."

CREMASTUS (ZALEPTOPYGUS) ATTENUATUS, new species.

Chiefly remarkable for its extreme slenderness, being reminiscent in this respect of the genus Eiphosoma Cresson, and for the fact that the first tergite completely encircles the petiole. In the latter character it resembles anomalus Cushman, to which the female runs in my key on most of the characters. The male of the latter species is unknown and the male of attenuatus runs on most of the characters to bilineatus Cushman, from which it differs in the petiolar character, habitus, and color of the abdomen.

Female.-Length, $12 \mathrm{~mm}$; antennae, $8 \mathrm{~mm}$; ovipositor, $2 \mathrm{~mm}$.

Head barely as wide as thorax, very narrow behind eyes, temples weakly convex; diameter of lateral ocellus subequal to ocell-ocular line, which is barely half as long as postocellar line; face and frons very finely, densely punctate, the former with a minute polished tubercle above; malar space as long as basal width of mandible; clypeus convex, broadly rounded at apex, nearly as long as interfoveal line; thorax and propodeum minutely, densely punctate, thorax laterally and propodeum entirely clothed with long, dense, silvery pubescence; scutellum weakly carinate laterally; propodeum arcuate from base to apex, extending only a short distance beyond base of coxae, insertion of petiole far down between coxae, petiolar area much longer than areolet, latter much longer than wide, distinctly separated from petiolar area; legs very slender; stigma less than half as wide as long, but with radius distinctly beyond middle; 
apical abscissa of radius sinuate; intercubitus oblique, upper end beyond lower, radius thickened at its point of junction, recurrent slightly beyond intercubitus, distinctly more than half as long as first abscissa of subdiscoideus; nervulus slightly antefurcal; nervellus strongly antefurcal, broken very close to submediella; abdomen very slender, first and second tergites subequal in length and together as long as rest of abdomen; first tergite polished, completely encircling petiole, postpetiole nearly twice as long as wide; second tergite about six times as long as basal width, inconspicuously striate medially, polished laterally; third tergite polished, gradually compressed toward apex; other tergites strongly compressed; ovipositor sheath barely as long as first tergite.

Black; nearly complete orbital rings, clypeus, mandibles, cheeks, tegulae, all coxae apically, trochanters more or less, front and middle femora in front and at apex, dorsal stripe on hind tibia, and tarsi basally yellow; coxae and basal joint of hind trochanters piceous at base, hind coxae largely so; hind tibiae, except dorsal stripe, piceous; scutellum and spot on each side of prescutum rufous; wings slightly stained; abdomen rufous, prceous at apex, second and third tergites blackish at base.

Male.-Very similar to female, but differing as follows: Malar space shorter than basal width of mandible; ocell-ocular line scarcely half as long as diameter of lateral ocellus; prescutal and scutellar spots yellow.

Type locality.-Victoria, Texas.

Type.-Cat. No. 22152, U.S.N.M.

One specimen of each sex collected May 8, 1911, on Stitlingia sylvatica by J. D. Mitchell.

\section{CREMASTUS (ZALEPTOPYGUS) DORCASCHEMAE, new species.}

Except that the abdomen is not distinctly red beyond the second tergite, but rather piceous, this species runs in the female to couplet 29 in my key and the male to obereae Viereck. The female differs from both of the species under couplet 29 in being normal with respect to all three of the subgeneric characters, in having the temples broad and strongly rounded, and the second tergite hardly three times as long as basal width. The male differs from obereae, in addition to the color of the abdomen, in having the wings hyaline and by other characters. In the color of the wings it agrees with orbus (Davis), from which the abdominal color will distinguish it.

Female.-Length, $7 \mathrm{~mm}$; antennae, $6 \mathrm{~mm}$; ovipositor, $3 \mathrm{~mm}$.

Head from above more than half as long as wide, temples, vertex, and cheeks subbuccate; face slightly wider than frons, densely shining pubescent; clypeus barely half as long as interfoveal line, broadly rounded at apex; malar space slightly shorter than basal width of 
mandible; orbits swollen above antennae; diameter of lateral ocellus equal to ocell-ocular line and one-half postocellar line; thorax and propodeum opaque shagreened, the shagreening interspersed with small punctures, denser and coarser laterally and on propodeum; lateral impression of mesopleurum polished above, striate below; areola pentagonal, nearly equal in length to the petiolar area, the costulae near anterior end; basal median area long triangular, more than half as long as areola; petiolar area transversely rugulose; stigma barely half as wide as long, the radius just beyond the middle; apical abscissa of radius straight, twice as long as basal; second recurrent slightly beyond intercubitus, more than half as long as basal abscissa of subdiscoideus, latter at upper third of apex of second discoidal cell; nervellus antefurcal, broken very near base; legs slender; abdomen with first two tergites longitudinally striate, others shagreened; first tergite no longer than dorsal length of propodeum; second somewhat shorter than first, hardly three times as long as basal width; ovipositor about as long as first three tergites.

Black, tergites beyond second piceous, narrowly reddish at apex, especially above; orbits, with narrow interruptions opposite ocelli and in malar space, cheeks, mandibles at base, clypeus, median spot on face, scape, and pedicel beneath, and apices of flagellar joints yellow; wing base, costa, and streak on costal margin of stigma whitish; wings hyaline, venation, except as noted, dark brown; front and middle legs stramineous with coxae and trochanters in front white, tibiae and tarsi more or less fusco-testaceous; hind coxae and trochanters piceous, apices whitish; femur fusco-testaceous with a white spot exteriorly at apex; tibia and tarsus fuscous, calcaria white.

Male.-Length, $10 \mathrm{~mm}$; antennae, $8 \mathrm{~mm}$.

The allotype is much larger than the type female, and differs otherwise principally as follows: Ocelli distinctly longer than ocellocular line and equal to postocellar line, which is not nearly twice as long as ocell-ocular line; malar space barely half as long as basal width of mandible; apex of clypeus black; face without median yellow spot; antennae black with only apices, of scape, pedicel, and flagellar joints yellow; propodeal carinae very strong and high; hind coxae testaceous, piceous at extreme base, their trochanters and femora also paler than in female, tibiae and tarsi nearly black.

Host.-Dorcaschema nigrum Say.

Type locality.-Syracuse, New York (?).

Type.-Cat. No. 22153, U.S.N.M.

Described from one specimen of each sex reared by M. W. Blackman at Syracuse, New York, from hickory infested by the host and other species of Coleoptera, the cocoons being found in the pupal cells of Dorcaschema nigrum. 'The type is labeled "H-88," and the allotype "H-583." 


\section{Family BRACONIDAE.}

BASSUS ACROBASIDIS, new species.

Female.-Length, $6 \mathrm{~mm}$; ovipositor, $4 \mathrm{~mm}$.

Head polished, impunctate, in front view wider by the width of one eye than long; face nearly a half wider than greatest diameter of eye, rather densely pilose; eyes parallel within; malar space twothirds as long as eye; clypeus truncate, labrum exposed to about the length of clypeus; thorax polished, pilose, especially on pleura and propodeum; posterior margins of pronotum and mesopleurum and metapleural furrow foveolate; notauli weak anteriorly, but deep for a short distance before their junction; fovea between scutellum and mesoscutum finely foveolate; legs stout, hind femur more than a third as deep as long; abdomen polished, equal in length to head and thorax together; first tergite as broad at apex as long, with dorsal carinae strong and parallel basally, becoming obsolete and divergent toward apex, the segment longitudinally rugulose beyond middle, polished medially at apex; second tergite with deep transverse gastrocoeli, longitudinally aciculate at sides; suturiform articulation, apex of third tergite, and groove across fourth tergite finely foveolate; ovipositor two-thirds as long as body.

Head, antennae, front and middle legs, and thorax except pronotum, metapleura, and propodeum black; (the red pronotum is very unusual in the group to which this species belongs and in this case is probably due to immaturity $)^{1}$; excepted portions of thorax, hind legs (except apices of tibiae and tarsi, which are black), and abdomen red; wings dark infumate.

Male.-Practically identical with female but normal in thoracic coloration.

As is usual in this genus there is great variation in sculpture. All the furrows and sutures mentioned above as foveolate vary from strongly so to practically smooth. This is especially true of those on the abdomen. The propodeum varies from practically smooth with sparse punctures to strongly, irregularly rugulose, the rugae sometimes arranged to form rather distinct areolation. The hind tibia in the male is sometimes very largely fuscous, paler in the middle and at base.

Host.-Acrobasis, species on pecan; Acrobasis caryaevorella.

Type locality.-Brownwood, Texas.

Other localities.-Pecan Bayou, Glen Rose, and College Station, Texas.

Type-Cat. No. 22867, U.S.N.M.

'Since this description was written more specimens have been received from both Mr. Bilsing and $\mathrm{Mr}$. Fabis. Of the 13 new specimens only one female has the pronotum red.

181404-21-Proc.N.M.vol.58-19 
Described from one female and seven males. The type, allotype, and paratypes $a-d$ were reared from Acrobasis, species by A. I. Fabis the type, allotype, and paratype $a$ under Quaintance No. 16787; paratypes $b-d$ from Pecan Bayou, under Quaintance Nos. 16926 ( $a$ ) and $16929(c-d)$; paratype $e$ from Glen Rose, under Quaintance No. 16859 ; while paratype $f$ was reared by S. W. Bilsing from Acrobasis caryaevorella at College Station.

\section{ORGILUS MACULIVENTRIS (Cresson). ${ }^{1}$}

Eubadizon maculiventris Cresson, Trans. Amer. Ent. Soc., vol. 4, 1872, p. 178.

In Ashmead's key to the tribe Orgilini runs to Orgilus on the first of the two characters under couplet 2 and to Oresimus on the other. It is very closely allied to lateralis Cresson and kearfotti Ashmead. From the former it differs in having the face very sparsely and weakly punctate; the propodeum less densely punctate, the punctuation not having the appearance of deep reticulation; the abdomen opaque granulate but impunctate; the first tergite fully two-thirds as broad at apex as long; the second tergite much broader at base than long medially; in being entirely ferruginous; and in having the ovipositor as long as the body. From kearfotti, which is known only from the unique type, it differs in the broader first and second tergites and in the abdominal sculpture.

Female.-Length, $4 \mathrm{~mm}$; ovipositor, $4 \mathrm{~mm}$.

Face polished, sparsely, weakly punctate, a third wider than greatest diameter of eye; thorax polished, mesoscutum obscurely, sparsely punctate, densely and coarsely punctate at junction of notauli; longitudinal furrow of mesopleurum strongly $\sim$-shaped, weakly foveolate; propodeum opaque granulate at sides, coarsely and rather densely punctate in middle; longer spur of hind tibia more than half as long as basitarsus; first abscissa of radius much shorter than intercubitus, second abscissa forming a distinct angle with intercubitus; stub of third abscissa of cubitus very short; nervulus postfurcal by half its length; subdiscoideus at basal third of apical abscissa of discoideus; abdomen largely opaque granulate; first tergite about two-thirds as wide at apex as long; second much broader at base than long; ovipositor as long as body.

Pale ferruginous; ocellar triangle black; legs stramineous, hind legs slightly testaceous; apex of bind femur black; tibia fuscous, paler in middle and with a broad white basal annulus, calcaria white; tarsi black; wings hyaline.

Host.-Acrobasis, species.

One female, reared June 15, 1918, under Quaintance No. 16784 by A. I. Fabis, at Brownwood, Texas.

1 In the manuscript as originally submitted this species was described as new under another name from a single female. The subsequent receipt of another female and a male from the same source proves it to be Cresson's species. Since the sexes differ so markedly in color, the description is not withdrawn 
ORGILUS GELECHIAEVORA, new species.

Related to maculiventris (Cresson) and differing principally as follows.

Female.-Length, $3.5 \mathrm{~mm}$; ovipositor, $2.5 \mathrm{~mm}$.

Face granularly opaque, scarcely a fourth wider than length of eye; pronotum irregularly roughened; furrow of mesopleurum weakly curved; metapleurum opaque coriaceous; propodeum irregularly, transversely rugulose, with a distinct, medially interrupted apical carina; apical abscissa of radius and intercubitus forming a nearly straight line; stub of cubitus fully as long as second abscissa; nervulus postfurcal by less than half its length; abdomen about as in maculiventris; ovipositor shorter than body.

Bright ferruginous; ocellar triangle not black; legs testaceous, trochanters paler, tarsi and apices of hind femur and tibia fuscous; wings very slightly infumate.

Host.-Gelechia trialbamaculella Chambers.

Type locality.-Whitesbog, New Jersey.

Type.-Cat. No. 22869, U.S.N.M.

One female reared July 12, 1916, under Quaintance No. 12789, by H. B. Scammell.

\section{HABROBRACON GELECHIAE (Ashmead).}

Since my revision of this genus was published ${ }^{1} \mathrm{I}$ have reared a large number of specimens of gelechiae from the grape berry moth. These show variation from the broad abdomen of the type to the tapering abdomen of johannseni Viereck. They agree further with the type in the color of the legs and in the male in color of abdomen. The last constitutes the only apparently constant character that I have been able to discover, and were it not for this I would be inclined to synonymize the two species.

HABROBRACON ERUCARUM, new species.

In my key to the North American species of Habrobracon runs to the last couplet, where it agrees in abdominal characters of the female with gelechiae (Ashmead) and in color of male with johannseni Viereck. From both it differs in having the scutellum flattened and subpolished, the propodeum with a median longitudinal carina at apex, and in the ovipositor being only about as long as the second tergite (in both gelechiae and johannseni the ovipositor is about twice as long as the second tergite). The entire body is somewhat moro shining than in either of the other species, and the wings are less distinctly clouded with darker venation. 
Female.-Length, $2.5 \mathrm{~mm}$; antennae (broken).

Body shining, granular; scutellum, and apical tergites subpolished, the sculpture weak, former with a few punctures; abdomen broad, rounded at apex; ovipositor subequal in length to second tergite.

Black; upper and lower anterior orbits and mouth brownish; legs blackish with articulations paler; wings only very indistinctly brownstained, venation very dark brown; abdomen entirely black.

Male.-Much like female; abdomen rather broader than usual.

Host.-Euxoa, species.

Type locality.-Vernal, Utah.

Type.-Cat. No. 22870, U.S.N.M.

One female and three males reared by S. J. Snow on June 7 and 19, 1916, under Webster No. 16615. The type, allotype, and paratype $a$ also bear the cage No. 2026 I.A, while paratype $b$ is labeled 2026 A.B.U. In the allotype, the only specimen having an entire antenna, this is rather stout filiform and 25 -jointed.

(TRACHYUSA) HABROBRACON AMERICANA (Ashmead) Gahan.

In my key to North American species runs to couplet 5 , but differs from the two species falling there and from erucarum Cushman described above in having the malar space very long and the cheeks perfectly straight, the head in front view having a somewhat Agathidine appearance. 


\section{$2 \mathrm{BHL}$ Biodiversity Heritage Library}

Cushman, R. A. 1921. "North American Ichneumon-flies, new and described, with taxonomic and nomenclatorial notes." Proceedings of the United States National Museum 58, 251-292.

https://doi.org/10.5479/si.00963801.58-2334.251.

View This Item Online: https://www.biodiversitylibrary.org/item/31770

DOI: https://doi.org/10.5479/si.00963801.58-2334.251

Permalink: https://www.biodiversitylibrary.org/partpdf/17870

\section{Holding Institution}

Smithsonian Libraries

\section{Sponsored by}

Smithsonian

\section{Copyright \& Reuse}

Copyright Status: NOT_IN_COPYRIGHT

This document was created from content at the Biodiversity Heritage Library, the world's largest open access digital library for biodiversity literature and archives. Visit BHL at https://www.biodiversitylibrary.org. 